\title{
Photoacclimation and non-photochemical quenching under in situ irradiance in natural phytoplankton assemblages from the Amundsen Sea, Antarctica
}

\author{
Anne-Carlijn Alderkamp ${ }^{1,2, *}$, Matthew M. Mills ${ }^{1}$, Gert L. van Dijken ${ }^{1}$, \\ Kevin R. Arrigo ${ }^{1}$ \\ ${ }^{1}$ Department of Environmental Earth System Science, Stanford University, Stanford, California 94019, USA \\ ${ }^{2}$ Department of Ocean Ecosystems, Energy and Sustainability Research Institute, University of Groningen, 9747 AG, Groningen, \\ The Netherlands
}

\begin{abstract}
Photoacclimation strategies and sensitivity to photoinhibition were determined in natural phytoplankton assemblages during a phytoplankton bloom in the Amundsen Sea (Southern Ocean) in relation to community composition, pigment content, light, and iron (Fe). Nonphotochemical quenching $(q N)$ was measured during recovery after surface irradiance exposure (SIE) for $20 \mathrm{~min}$. The $q N$ was separated into slow ( $q I$, photoinhibition through damage of Photosystem II) and fast ( $q E$, xanthophyll cycling) relaxing components. Phytoplankton within the upper mixed layer (UML) showed a higher ratio of photoprotective xanthophyll cycle pigments (diadinoxanthin [DD] + diatoxanthin [DT]) to chlorophyll a ( $\mathrm{chl} a$ ), indicative of acclimation to high light, which resulted in lower photoinhibition after SIE when compared to phytoplankton residing below the UML. Within the UML, we found differences in photoacclimation strategies in assemblages dominated by Antarctic diatoms versus Phaeocystis antarctica (Haptophyta). Diatoms had a higher ratio of (DD + DT)/chl $a$, and the ratio tracked mean light levels within the UML, whereas this relationship was not apparent in P. antarctica, which had a lower (DD + DT)/chl a ratio. Despite these differences, diatoms and $P$. antarctica exhibited similar degrees of $q N$ that were dominated by $q E$ with very little $q I$. Bioassays under high and low Fe concentrations revealed an increase in the $(\mathrm{DD}+\mathrm{DT}) / \mathrm{chl}$ a ratio in Fe-limited populations dominated by diatoms and decreased photoinhibition. In experiments dominated by $P$. antarctica or with mixed populations, acclimation to low Fe increased the (DD + DT)/chl a ratio in most experiments; however, this did not affect photoinhibition. This study shows that under in situ conditions in the Amundsen Sea (1) phytoplankton photoacclimation efficiently minimizes photoinhibition, (2) photoinhibition does not control the relative abundances of $P$. antarctica or Antarctic diatoms, and (3) Fe limitation does not increase photoinhibition of either P. antarctica or Antarctic diatoms.
\end{abstract}

KEY WORDS: Amundsen Sea · Diatoms · Iron · Non-photochemical quenching $\cdot$ Phaeocystis antarctica $\cdot$ Photoacclimation $\cdot$ Photoinhibition $\cdot$ Xanthophyll cycle

\section{INTRODUCTION}

Phytoplankton primary productivity in the Southern Ocean plays an important role in modulating the global climate system by taking up anthropogenic $\mathrm{CO}_{2}$ and exporting it to the deep sea (Lovenduski \&
Gruber 2005). In particular, coastal Antarctic ecosystems are highly productive (Arrigo et al. 2008a, Vernet et al. 2008, Long et al. 2011) and strong sinks for atmospheric $\mathrm{CO}_{2}$ (Arrigo et al. 2008b). Productivity in most of the coastal Antarctic is thought to be limited by iron (Fe) or co-limited by Fe and light (Sedwick \& 
DiTullio 1997, Sunda \& Huntsman 1997, Boyd 2002). Low atmospheric and continental Fe inputs result in low $\mathrm{Fe}$ concentrations throughout the Southern Ocean (Boyd 2002, De Baar et al. 2005), while light availability depends on season, cloud cover, ice cover, depth of the upper mixed layer (UML), and attenuation within the water column.

High wind speeds in the Antarctic result in deep wind-driven vertical mixing of the water column, reducing the mean light availability to phytoplankton in the UML, but exposing them to short periods of high irradiance when they are mixed up to the surface (Denman \& Gargett 1983). Thus, phytoplankton cells need to adjust their photosynthetic apparatus for optimal carbon fixation while minimizing photoinhibition due to damage to photosystems induced by excessive photosynthetically active radiation (PAR) and/or ultraviolet radiation (UVR) (MacIntyre et al. 2000). Photosystem II (PS II), most notably its D1 core protein, is more sensitive to photodamage than the rest of the photosynthetic apparatus (Aro et al. 1993). Photodamaged PS II reaction centers can be repaired via degradation and synthesis of the D1 protein, although this is a metabolically expensive pathway (Aro et al. 1993, Hazzard et al. 1997).

Photoacclimation to high irradiance decreases the effects of photodamage by reducing photosynthetic pigment content, thereby preventing the overexcitation of PS II that leads to photodamage (Falkowski \& LaRoche 1991). Moreover, photoprotective mechanisms that involve non-photochemical quenching $(q N)$ of excitation energy also prevent overexcitation of PS II. An important component of $q N$ is the thermal dissipation of excess energy via the xanthophyll pigment cycle. The xanthophyll cycle consists of enzymatic de-epoxidation of carotenoids such as diadinoxanthin (DD) to diatoxanthin (DT), the latter of which thermally dissipates excess energy (Olaizola \& Yamamoto 1994, Demmig-Adams \& Adams 2006, Goss \& Jakob 2010). Most xanthophyll de-epoxidation reverses at low irradiance on a time scale of minutes, which causes the $q N$ to relax. Thus, $q N$ related to xanthophyll cycling can be measured as fast-relaxing quenching $(q E)$. The $q N$ that results from photoinhibition relaxes through repair of damaged proteins such as D1, which is a slow process on a time scale of minutes to hours. This slow-relaxing photoinhibitory quenching is measured as qI (Maxwell \& Johnson 2000).

Diatoms and Phaeocystis antarctica (Haptophyta) are 2 groups that dominate the phytoplankton community in most of the Southern Ocean, including productive polynyas such as those in the Ross Sea and
Amundsen Sea (Schoemann et al. 2005, Wright et al. 2010, Alderkamp et al. 2012a). Laboratory studies as well as field observations suggest that there are taxon-specific differences between $P$. antarctica and Antarctic diatoms in the balancing of $\mathrm{CO}_{2}$ fixation and photoprotection (Kropuenske et al. 2009, Mills et al. 2010, Van de Poll et al. 2011). The photosynthetic properties of $P$. antarctica allow for efficient usage of light when grown under a variable light regime, and therefore this species is adapted to grow efficiently in areas with a deep UML (Mills et al. 2010). Conversely, Antarctic diatoms such as Fragilariopsis cylindrus and Chaetoceros brevis contain higher levels of DD + DT, resulting in higher $q E$ and better protection from photoinhibition (Kropuenske et al. 2009, Van de Poll et al. 2011). Thus, diatoms are better adapted to grow in the high-light environment typical of shallow UMLs (Arrigo et al. 2003, Kropuenske et al. 2009, Mills et al. 2010).

There are strong interactions between Fe limitation and photoinhibition. For example, Fe limitation decreases the synthesis of photosynthetic proteins such as the D1 reaction center protein (Greene et al. 1992, Vassiliev et al. 1995). On the other hand, Felimited cells generally contain less chlorophyll a (chl a), which decreases the potential for absorption of excess irradiance (Greene et al. 1992, Van de Poll et al. 2005, Van Leeuwe \& Stefels 2007). Moreover, Fe limitation may increase either the cellular xanthophyll cycle pigment content (Van Leeuwe \& Stefels 2007) or its ratio to light-harvesting pigments (Van Leeuwe \& Stefels 1998, Alderkamp et al. 2012b). Finally, Fe limitation has been shown to either increase, decrease, or have no effect on photoprotective mechanisms such as $q N$, depending on phytoplankton species and experimental conditions (Strzepek \& Harrison 2004, Allen et al. 2008, Van de Poll et al. 2009). Thus, the net effect of Fe limitation on photoinhibition is unclear.

In the present study, we characterized photoprotective and photoinhibition mechanisms of natural phytoplankton assemblages dominated by Phaeocystis antarctica and diatoms when exposed to excessive in situ surface irradiance in the highly productive polynya system of the Amundsen Sea. We assessed whether photoacclimation mechanisms included adjustment of photoprotective pigment composition, and whether these adjustments in turn affected the degree of $q E$ and $q I$ when exposed to surface irradiance. Finally, we assessed whether acclimation to low Fe concentrations impacted the mechanisms involved in photoprotection and photoinhibition. 


\section{MATERIALS AND METHODS}

\section{In situ sampling}

Seawater samples were collected from 47 stations during the NBP 09-01 cruise on the RV 'Nathaniel B. Palmer' in the Amundsen Sea area during the austral summer from 12 January to 17 February 2009 (Fig. 1). Vertical profiles of temperature, salinity, fluorescence, irradiance, and suspended particle abundance were obtained from the water column using a SeaBird 911+ conductivity, temperature, and depth (CTD) sensor, a Chelsea fluorometer, a PAR sensor (Biospherical), and a $25 \mathrm{~cm}$ WET Labs transmissometer, respectively, on a cast preceding collection of water samples. Water was sampled from discrete depths in the upper $300 \mathrm{~m}$ of the water column with 12 l GO-FLO samplers (General Oceanics) using trace metal clean (TMC) techniques (Gerringa et al. 2012). Sampling depths were typically 10, 25, 50, 100, 200, and $300 \mathrm{~m}$.

Temperature, salinity, and derived density data were binned into $1 \mathrm{~m}$ intervals. The attenuation of downwelling PAR in the water column $\left(K_{\mathrm{d}}\right)$ was calculated from each PAR profile as described in Alderkamp et al. (2012a). The depth of the UML

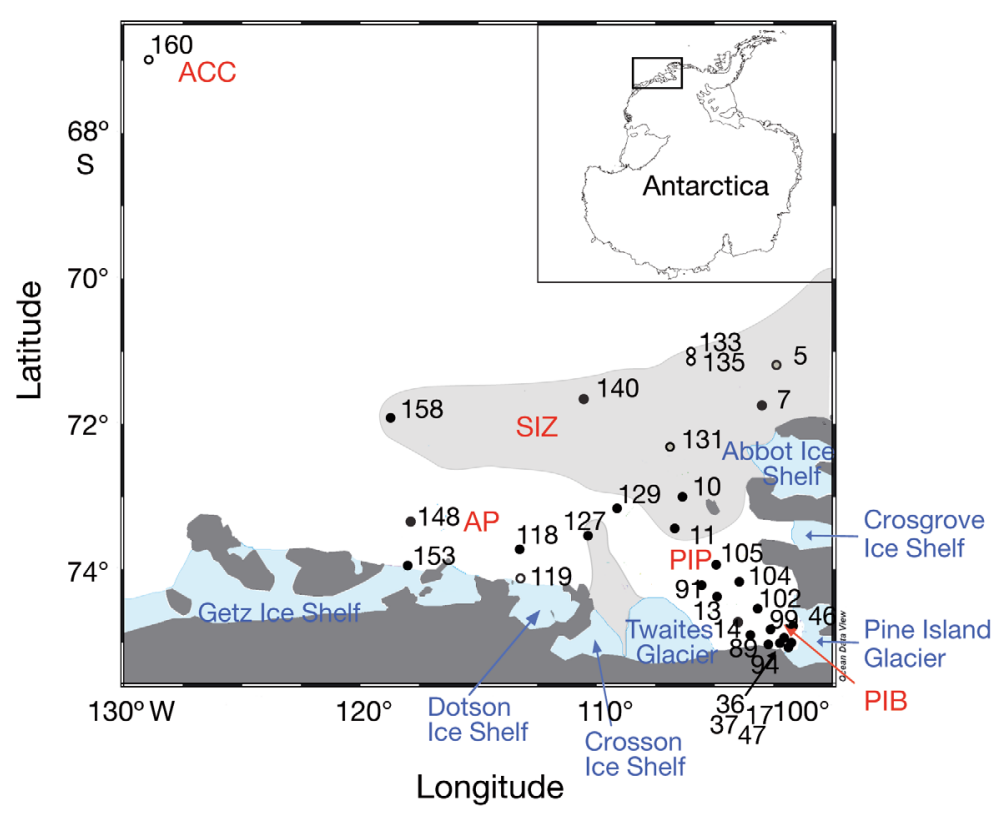

Fig. 1. Stations in the Amundsen Sea, with Amundsen Polynya (AP) to the west, Pine Island Polynya (PIP) to the east, and Pine Island Bay (PIB) bordering the Pine Island Glacier. Ice shelves are light blue and marked by blue text, and the area with $>50 \%$ sea ice concentration at the time of sampling is shaded light grey. Stations were dominated by Phaeocystis antarctica (filled black circle), diatoms (white circle outlined in black), or a mixed community (grey circle outlined in black). Stn 160 was located in the Antarctic Circumpolar Current (ACC)
$\left(\mathrm{Z}_{\mathrm{UML}}\right)$ was determined for each CTD profile as the shallowest depth at which the density $\left(\sigma_{t}\right)$ was $0.02 \mathrm{~kg} \mathrm{~m}^{-3}$ greater than at the surface. The diffuse $K_{\mathrm{d}}, z_{\mathrm{UML}}$, and mean incident irradiance over the previous $5 \mathrm{~d}$ were used to calculate the mean PAR in the UML ( $\left.E_{\mathrm{UML}}\right)$ as described in Alderkamp et al. (2012a). Dissolved Fe (DFe) concentrations were determined from 44 stations as described in Gerringa et al. (2012).

\section{Pigments}

Phytoplankton were collected by filtering 0.2 to 1.01 of seawater onto GF/F filters (25 mm, Whatman) under gentle vacuum pressure. Filters for determination of chl a were extracted overnight in $90 \%[\mathrm{v} / \mathrm{v}$ ] acetone and measured on a Turner Designs fluorometer before and after acidification (Holm-Hansen et al. 1965). Filters for determination of pigment composition by high-pressure liquid chromatography (HPLC) were immediately flash-frozen in liquid nitrogen and stored at $-80^{\circ} \mathrm{C}$ until analysis. Chl $a_{\text {, }}$ chlorophyll $C_{3}\left(\mathrm{chl} C_{3}\right), 19^{\prime}$-butanoyloxyfucoxanthin (19'-But), fucoxanthin (Fuc), 19'-hexanoyloxyfucoxanthin $(19$ '-Hex), DD, and DT were quantified as described in Alderkamp et al. (2012a). Pigment composition derived from HPLC analysis was used to determine the phytoplankton community composition based on CHEMTAX analysis (Mackey et al. 1996, Wright et al. 1996) as described in Alderkamp et al. (2012a) and to determine the photoprotective pigment ratio of (DD + $\mathrm{DT}) / \mathrm{chl}$ a.

\section{Fluorescence parameters}

The maximum photochemical efficiency of PS II $\left(F_{\mathrm{v}} / F_{\mathrm{m}}\right.$, the ratio of variable fluorescence $F_{\mathrm{v}}$ to maximum fluorescence $F_{\mathrm{m}}$ ) was determined using a pulse-amplitude modulated (PAM) fluorometer (Water PAM, Heinz Walz) at ambient seawater temperature. Prior to analysis, the PAM was blanked with GF/F-filtered seawater from the same station. After sampling from the GO-FLO bottles, phytoplankton samples were acclimated in the dark at ambient seawater temperature for $30 \mathrm{~min}$ to fully oxidize the photosynthetic reaction centers and epoxidate the xantho- 
phyll cycle pigments. Minimum fluorescence $\left(F_{0}\right)$ and $F_{\mathrm{m}}$ were measured on triplicate $4 \mathrm{ml}$ subsamples. $F_{\mathrm{o}}$ was determined using the measuring (non-photochemistry-inducing) light of the PAM, and $F_{\mathrm{m}}$ was measured by applying a saturating light pulse of $4000 \mu \mathrm{mol}$ photons $\mathrm{m}^{-2} \mathrm{~s}^{-1}$ for $0.8 \mathrm{~ms}$ to close all PS II reaction centers. The maximum dark-acclimated efficiency of PS II $\left(F_{\mathrm{v}} / F_{\mathrm{m}}\right)$ was calculated as (Krause \& Weis 1991):

$$
F_{\mathrm{v}} / F_{\mathrm{m}}=\frac{F_{\mathrm{m}}-F_{\mathrm{o}}}{F_{\mathrm{m}}}
$$

\section{Surface irradiance exposure experiments}

The sensitivity of phytoplankton photosynthesis to various levels of in situ surface irradiance exposure (SIE) was tested as described by Alderkamp et al. (2010, 2011). Briefly, at 30 stations, phytoplankton from the surface $(S)$ and the subsurface $\left(D_{i}\right.$ see Table 2 for sampling depth) were exposed to nearsurface irradiance (see Tables 1 \& 2) for 20 min while floating in a deck incubator at in situ water temperature in $50 \mathrm{ml}$ polystyrene culture flasks (Becton Dickinson). The polystyrene flasks were transparent to both PAR and ultraviolet A (UVA), whereas ultraviolet $B$ (UVB) was blocked, which was confirmed by measuring light absorption (200 to $800 \mathrm{~nm}$ ) by the wall of the flask on a Perkin-Elmer Lambda 35 spectrophotometer. After $20 \mathrm{~min}$ of SIE (time $[t]=20 \mathrm{~min}$ ), maximum $\left(F_{\mathrm{m}}^{\prime}\right)$ and minimum $\left(F_{\mathrm{o}}^{\prime}\right)$ fluorescence were determined without applying far-red illumination and compared to $F_{\mathrm{m}}$ and $F_{\mathrm{o}}$ measurements before SIE. The $q N$ was calculated as (Van Kooten \& Snell 1990):

$$
q N=1-\frac{F_{\mathrm{m}}^{\prime}-F_{\mathrm{o}}^{\prime}}{F_{\mathrm{m}}-F_{\mathrm{o}}}
$$

The $q N$ represents the ratio of quenched to maximum variable fluorescence and can be used to compare quenching characteristics of phytoplankton with a range of variable fluorescence. The $q N$ may also be calculated as NPQ, which represents the ratio of quenched to remaining fluorescence using the Stern-Volmer equation (Krause \& Weis 1991); however, NPQ may underestimate $q N$ when $F_{\mathrm{v}}$ is low (Krause \& Weis 1991, Maxwell \& Johnson 2000, Lavaud et al. 2007). Moreover, the NPQ calculation requires a stable fluorescence baseline over the time of the measurement (110 min). In our study, variations in the baseline, due either to phytoplankton biomass near the detection limit of the PAM fluorometer (Alderkamp et al. 2010) or sample heterogeneity when colonial Phaeocystis antarctica was dominant, produced inconsistent values of NPQ.

Following SIE, samples were placed at low light (5 $\mu \mathrm{mol}$ photons $\mathrm{m}^{-2} \mathrm{~s}^{-1}$ ) under cool white fluorescent lamps at ambient seawater temperature to monitor recovery for $2 \mathrm{~h}$, during which $F_{\mathrm{v}} / F_{\mathrm{m}}$ was measured at approximately 30 min intervals after dark acclimation for $5 \mathrm{~min}$. Two treatments were tested, one with no addition of metabolic inhibitors and the other with the addition of $0.6 \times 10^{-3} \mathrm{~mol} \mathrm{l}^{-1}$ (final concentration) of lincomycin (Sigma, from a 100x stock solution freshly prepared in $96 \%$ ethanol). Lincomycin inhibits transcription of chloroplast-encoded proteins such as the D1 reaction center protein (Bouchard et al. 2005). Experiments were carried out in triplicate, and a single control sample for each treatment was not exposed but kept at ambient seawater temperature under low light ( $5 \mu \mathrm{mol}$ photons $\mathrm{m}^{-2} \mathrm{~s}^{-1}$ ).

The short dark acclimation time for $F_{\mathrm{v}} / F_{\mathrm{m}}$ measurements during recovery allowed us to resolve relaxation of $q N$, so that both $q E$ and $q I$ could be determined in the treatments without lincomycin (Alderkamp et al. 2010). Briefly, measurements of $F_{\mathrm{v}} / F_{\mathrm{m}}$ after $30 \mathrm{~min}$ of recovery $(t=50 \mathrm{~min}$ to $t=$ $110 \mathrm{~min}$ ) were linearly regressed and extrapolated back to the time immediately after SIE ( $t=20 \mathrm{~min})$ to determine the value of $q N$ that would have been attained if only $q I$ had been present; $q E$ was then calculated as the difference between $q N$ and $q I$ (Maxwell \& Johnson 2000, Kropuenske et al. 2009).

\section{Bioassays}

Fe effects on the (DD + DT)/chl a ratio and quenching parameters were studied in bioassays, where Fe was added to the surface $(10 \mathrm{~m})$ phytoplankton community (see Table 3). Experimental details are described in Mills et al. (2012). Briefly, TMC 21 polycarbonate incubation bottles were randomly filled from GO-FLO bottles, Fe was added to the +Fe treatment (final concentration $4.0 \mathrm{nmol} \mathrm{l}^{-1}$ ), while no amendments were made to the control (C) treatment. Triplicate treatments of $+\mathrm{Fe}$ and $\mathrm{C}$ were incubated at in situ water temperature in deck incubators covered with neutral density screening to reduce the light level to $20 \%$ of in situ surface irradiance. After 4 to $5 \mathrm{~d}$, bottles were opened and analyzed for pigment content, and $F_{\mathrm{v}} / F_{\mathrm{m}}$ and quenching parameters were measured after SIE, as described in the previous section. Additional biochemical data are described in 
Mills et al. (2012). Fe effects on SIE were tested by comparing $+\mathrm{Fe}$ and $\mathrm{C}$ treatments of the same bioassay, allowing us to test for Fe effects on phytoplankton with an equal light history over the 4 to $5 \mathrm{~d}$ of the bioassay.

\section{Statistics}

Means are presented \pm SD. Data were checked for homoscedasticity and normality. Assumptions of homoscedasticity were always met, and data were $\log _{10^{-}}$ transformed when the assumption of normality was not met. Data were analyzed using 1-way ANOVA (Statistica, release 7, StatSoft) and accepted as significant at $\mathrm{p}<0.05$. Effects of sampling depth, lincomycin addition, and Fe additions on recovery after SIE were tested using repeated-measures ANOVA. Simple linear regression was used to examine the dependent relationships between measured variables.

\section{RESULTS}

\section{Chl a distribution, phytoplankton community composition, Fe, and light}

The Pine Island and Amundsen polynyas (PIP and $\mathrm{AP}$, respectively) are bordered by a band of sea ice to the north and by ice shelves to the south, which include several major glaciers such as the Pine Island Glacier (PIG), Dotson ice shelf, Crosson ice shelf, and Getz Glacier (Fig. 1). Dense phytoplankton blooms developed in surface waters of PIP, Pine Island Bay (PIB), and AP, and are described in detail in Alderkamp et al. (2012a). The phytoplankton blooms in the polynyas consisted of high surface (upper
$10 \mathrm{~m}$ ) chl a concentrations of up to $14 \mu \mathrm{g} \mathrm{l} \mathrm{l}^{-1}$ (Fig. 2A). The highest surface chl a concentration was found in the PIP and was largely restricted to the UML (Fig. 2B). Surface chl $a$ in PIB was lower than in the PIP, but the UML was deeper (Fig. 2E), resulting in similar depth-integrated chl a biomass (Alderkamp et al. 2012a). Considerable spatial heterogeneity was observed in surface chl $a$ of the AP, with chl a concentrations similar to the PIB. Chl a was also variable in the surrounding sea ice zone (SIZ), with mean chl a approximately half of that in the polynyas (Table 1). The lowest chl a concentrations in the SIZ were observed in the northeast region, and the highest were observed bordering the PIP and the AP. The phytoplankton community in the polynyas was consistently dominated by Phaeocystis antarctica, while in the SIZ, some stations were dominated by diatoms while others were either dominated by $P$. antarctica or had a mixed phytoplankton population (Fig. 1).

The phytoplankton bloom in PIB and PIP was fuelled largely by DFe input from the PIG (Gerringa et al. 2012). High DFe concentrations were observed in surface waters near the PIG $\left(>0.43 \mathrm{nmol} \mathrm{l}^{-1}\right)$ and Crosson Ice Shelf $\left(0.67 \mathrm{nmol} \mathrm{l}^{-1}\right)$, and lower DFe concentrations near the Dotson $\left(0.13 \mathrm{nmol} \mathrm{l}^{-1}\right)$ and Getz Ice Shelves (0.12 $\mathrm{nmol} \mathrm{l}^{-1}$; (Fig. 2C). Surface DFe concentrations decreased with distance from the ice shelves into the polynyas, while chl a concentrations increased (Fig. 2A,C), indicating uptake of DFe by phytoplankton. This resulted in very low DFe concentrations $\left(<0.09 \mathrm{nmol} \mathrm{l}^{-1}\right)$ in surface waters of the PIP. Surface DFe concentrations in the SIZ were similar to those in the polynyas but more variable (Table 1). In general, DFe concentrations increased with depth at all locations (Fig. 2D).

Mean daily light levels in the UML $\left(E_{\mathrm{UML}}\right)$ are calculated from incident irradiance, ice cover,

Table 1. Mean \pm SD of the depth of the upper mixed layer (UML) $\left(z_{\mathrm{UML}}\right)$, daily light in the UML ( $\left.E_{\mathrm{UML}}\right)$, dissolved iron (DFe) concentration, chl a concentration, photoprotective pigment ratio (diadinoxanthin [DD] + diatoxanthin [DT])/chl $a$, and maximum efficiency of Photosystem II $\left(F_{\mathrm{v}} / F_{\mathrm{m}}\right)$ at all stations, stations located in the Antarctic Circumpolar Current (ACC), sea ice zone (SIZ) and polynyas, and stations dominated ( $>50 \%$ of chl a) by diatoms, Phaeocystis antarctica, or mixed populations.

Means are significantly different if they are connected by the same symbol ${ }^{*} \mathrm{p}<0.05,{ }^{* *} \mathrm{p}<0.01,{ }^{* * *} \mathrm{p}<0.001$

\begin{tabular}{|lrcccccc|}
\hline & $\mathrm{n}$ & $\begin{array}{c}Z_{\mathrm{UML}} \\
(\mathrm{m})\end{array}$ & $\begin{array}{c}E_{\mathrm{UML}} \\
\left(\mu \mathrm{mol} \text { quanta } \mathrm{m}^{-2} \mathrm{~s}^{-1}\right)\end{array}$ & $\begin{array}{c}\mathrm{DFe} \\
\left(\mathrm{nmol} \mathrm{l}^{-1}\right)\end{array}$ & $\begin{array}{c}\mathrm{Chl} a \\
\left(\mu \mathrm{g} \mathrm{l} \mathrm{l}^{-1}\right)\end{array}$ & $(\mathrm{DD}+\mathrm{DT}) / \mathrm{chl} a$ & $F_{\mathrm{v}} / F_{\mathrm{m}}$ \\
\hline All stations & 47 & $25.8 \pm 23.9$ & $120 \pm 60$ & $0.15 \pm 0.20$ & $5.0 \pm 4.2$ & $0.12 \pm 0.05$ & $0.46 \pm 0.07$ \\
ACC & 1 & 37 & 111 & 0.04 & 0.36 & 0.09 & 0.30 \\
SIZ & 15 & $15.7 \pm 6.1$ & $119 \pm 52$ & $0.13 \pm 0.09$ & $3.1 \pm 3.0^{*}$ & $0.13 \pm 0.05$ & $0.47 \pm 0.07$ \\
Polynya & 31 & $30.3 \pm 28.0$ & $119 \pm 64$ & $0.17 \pm 0.23$ & $6.2 \pm 4.3^{*}$ & $0.11 \pm 0.04$ & $0.46 \pm 0.07$ \\
Diatoms & 8 & $23.3 \pm 12.1$ & $136 \pm 53$ & $0.11 \pm 0.03$ & $1.1 \pm 1.1^{* *}$ & $0.17 \pm 0.06^{* * *}$ & $0.44 \pm 0.09$ \\
P. antarctica & 37 & $26.8 \pm 26.3$ & $117 \pm 63$ & $0.19 \pm 0.24$ & $6.2 \pm 4.0^{* *}$ & $0.11 \pm 0.03^{* * *}$ & $0.46 \pm 0.06$ \\
Mixed & 2 & $17.5 \pm 10.6$ & $109 \pm 26$ & $0.20 \pm 0.02$ & $0.7 \pm 0.7$ & $0.11 \pm 0.08$ & $0.60 \pm 0.04$ \\
& & & & & & & \\
\hline
\end{tabular}



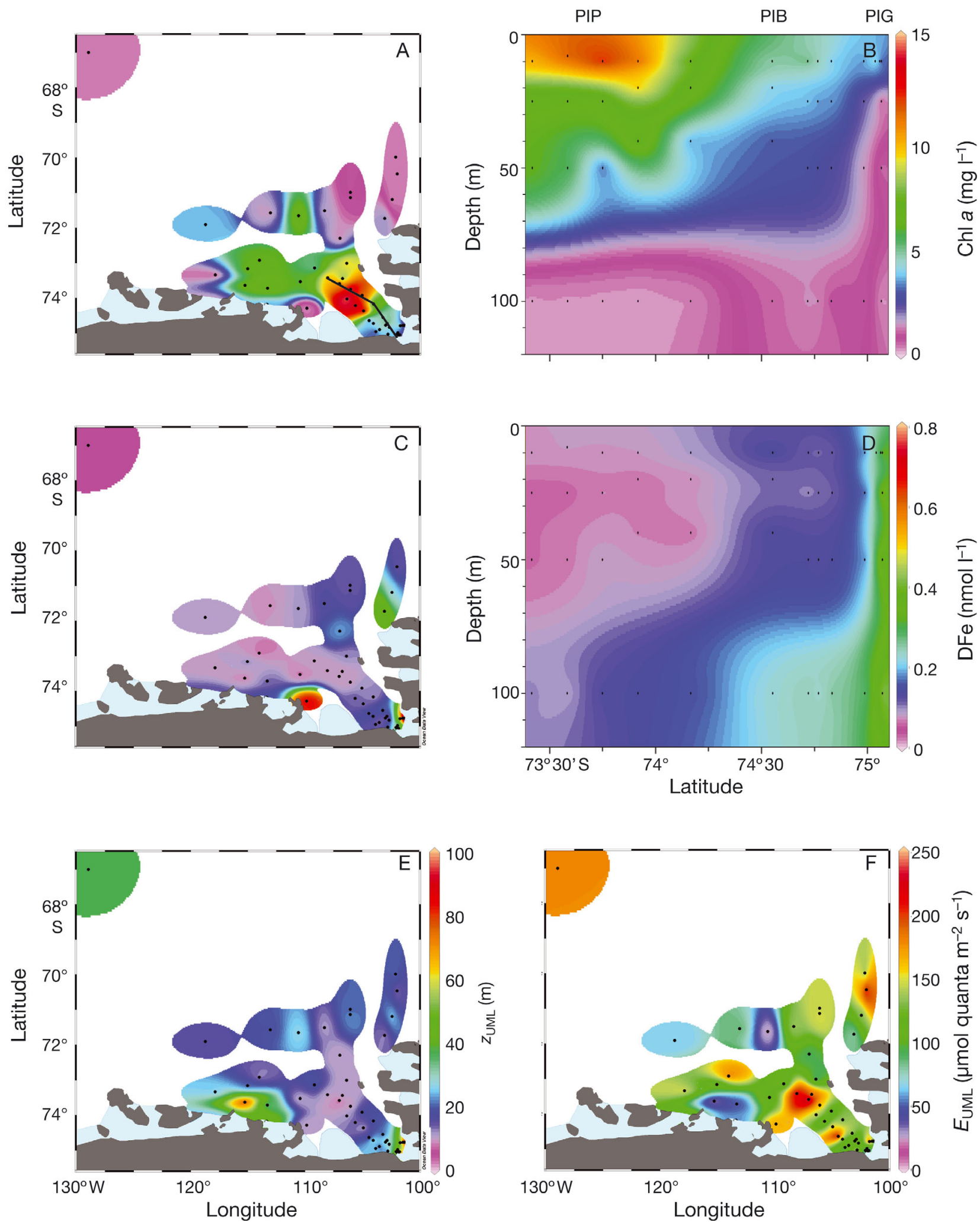

Fig. 2. $(A, B) C h l$ a concentration, $(C, D)$ dissolved iron (DFe) concentration, $(E)$ upper mixed layer $(U M L)$ depth $\left(Z_{U M L}\right)$, and $(F)$ mean photosynthetically active radiation (PAR) in the UML $\left(E_{\mathrm{UML}}\right)$. Characteristics are shown for $(\mathrm{A}, \mathrm{C})$ surface waters $(10 \mathrm{~m})$, as well as (B,D) the upper $100 \mathrm{~m}$ of the water column on a transect from the southwestern end of the Pine Island Glacier (PIG)

to the northwest, transecting the Pine Island Bay (PIB) and Pine Island Polynya (PIP) as shown with solid line in (A) 
$\mathrm{Z}_{\mathrm{UML}}$, and $K_{\mathrm{d}}$, the latter being primarily related to phytoplankton biomass. Since all these factors showed considerable spatial variation, the mean $E_{\text {UML }}$ in our study region ranged $>10$-fold, from 19 to $267 \mu \mathrm{mol}$ photons $\mathrm{m}^{-2} \mathrm{~s}^{-1}$, with a mean of $120 \pm 60 \mu \mathrm{mol}$ photons $\mathrm{m}^{-2} \mathrm{~s}^{-1}$ for all stations (Fig. 2F). In general, however, the lowest $E_{\mathrm{UML}}$ was observed at stations with a deep $Z_{\mathrm{UML}}$, while the highest were associated with a shallow $Z_{\mathrm{UML}}$. Surprisingly, the mean $E_{\mathrm{UML}}$ of SIZ stations was almost identical to that of polynya stations at $119 \mu \mathrm{mol}$ photons $\mathrm{m}^{-2} \mathrm{~s}^{-1}$ (Table 1), likely a consequence of high phytoplankton biomass in the polynya stations reducing light penetration. Likewise, there was no difference between the mean $E_{\mathrm{UML}}$ of Phaeocystis antarctica-dominated stations ( $>50 \%$ of $\mathrm{chl}$ a attributed to $P$. antarctica) and those dominated by diatoms (Table 1).

\section{Xanthophyll cycle pigments and phytoplankton fluorescence}

The mean photoprotective ratio (DD + DT)/chl $a$ of phytoplankton in surface waters was $0.12 \pm 0.05$ (wt/wt), with ratios ranging from 0.04 to 0.27 (Fig. 3A). The (DD + DT)/chl a ratio was higher at the surface than at depth, particularly below $z_{\mathrm{UML}}$ (Fig. 3B), indicating that phytoplankton acclimated to high light at the surface by increasing their (DD + $\mathrm{DT}) / \mathrm{chl}$ a ratio. The surface (DD $+\mathrm{DT}) / \mathrm{chl}$ a ratio in the SIZ (mean $0.13 \pm 0.05$ ) was not different from that of the polynyas (mean: $0.11 \pm 0.04$; Table 1 ). However, when stations were grouped according to their dominant phytoplankton class, diatom-dominated stations had a $55 \%$ higher $(\mathrm{DD}+\mathrm{DT}) / \mathrm{chl}$ a ratio (mean: $0.17 \pm 0.06$ ) than Phaeocystis antarcticadominated stations (mean: $0.11 \pm 0.03$; Table 1 ).
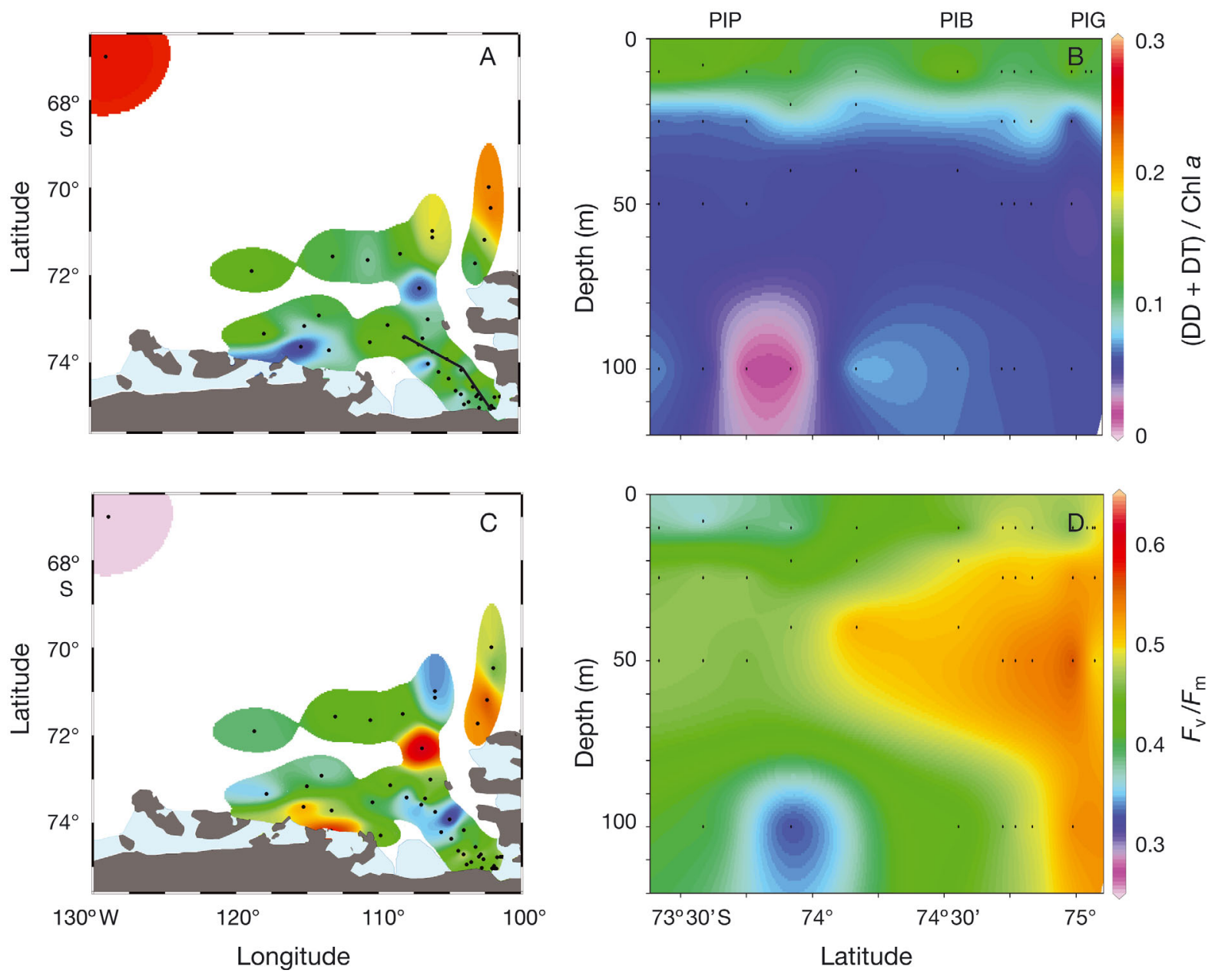

Fig. 3. $(\mathrm{A}, \mathrm{B})$ Photoprotective ratio of xanthophyll cycle pigments, (diadinoxanthin $[\mathrm{DD}]+$ diatoxanthin $[\mathrm{DT}]) / \mathrm{chl} a$, and $(\mathrm{C}, \mathrm{D})$ maximum efficiency of Photosystem II $\left(F_{\mathrm{v}} / F_{\mathrm{m}}\right)$, in $(\mathrm{A}, \mathrm{C})$ surface waters $(10 \mathrm{~m})$, as well as $(\mathrm{B}, \mathrm{D})$ the upper $100 \mathrm{~m}$ of the water column on the same transect as that described in Fig. 2, shown by solid line in (A) 

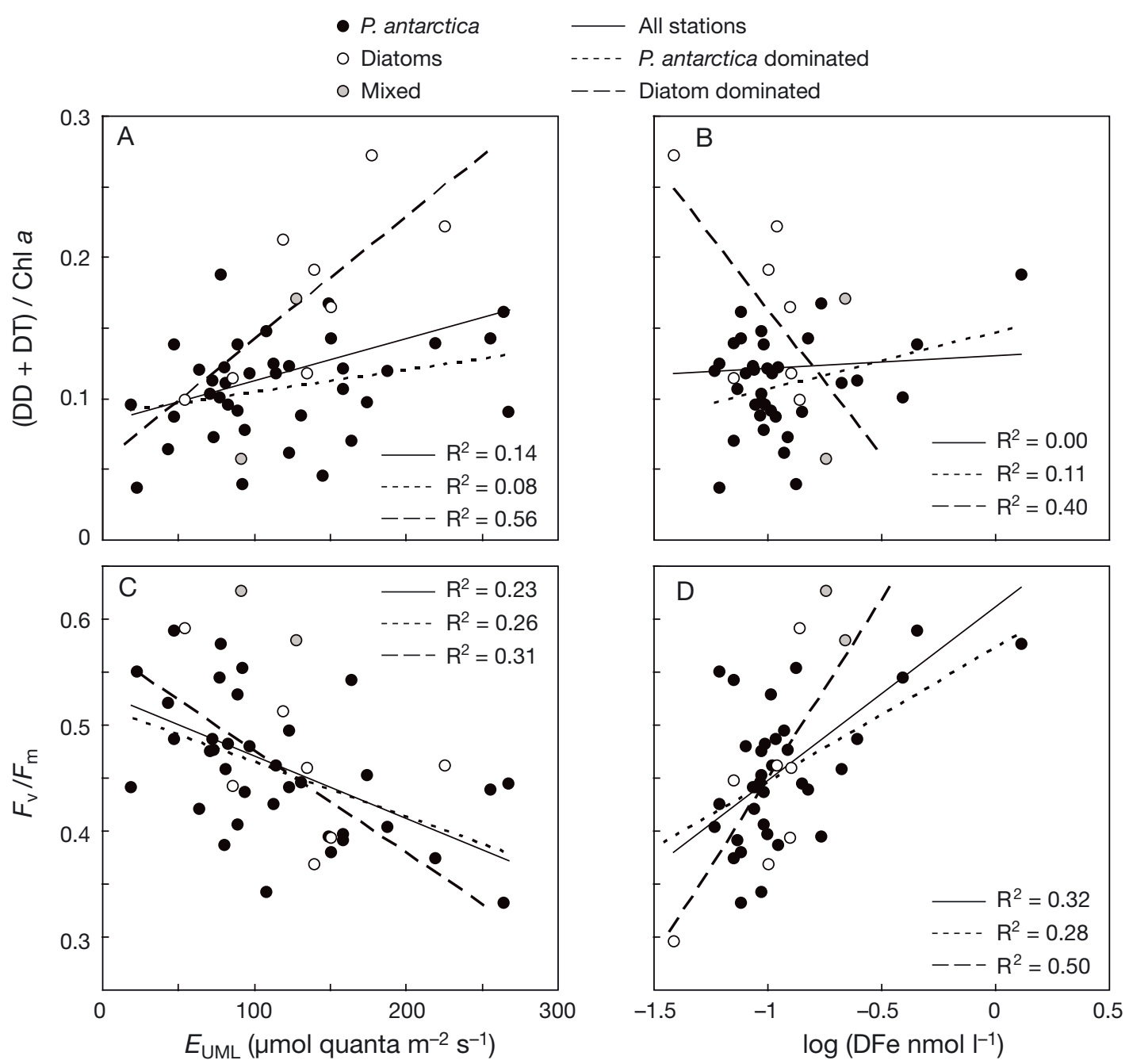

Fig. 4. Relationships of $(A, B)$ photoprotective ratio of xanthophyll cycle pigments, (diadinoxanthin [DD] + diatoxanthin $[\mathrm{DT}]) / \mathrm{chl} a$, and $(\mathrm{C}, \mathrm{D})$ maximum efficiency of Photosystem II $\left(F_{\mathrm{v}} / F_{\mathrm{m}}\right)$ in surface waters $(10 \mathrm{~m})$ to $(\mathrm{A}, \mathrm{C})$ mean photosynthetically active radiation (PAR) in the upper mixed layer $\left(E_{\mathrm{UML}}\right)$ and $(\mathrm{B}, \mathrm{D}) \log$ of dissolved iron $(\mathrm{DFe})$ concentration. $\mathrm{R}^{2}$ of simple linear regressions are shown; other statistics are given in Table 2

There was a weak, yet significant, positive relationship between the (DD $+\mathrm{DT}) / \mathrm{chl}$ a ratio of surface phytoplankton and $E_{\mathrm{UML}}$ for all stations (Fig. 4A, Table 2) with $E_{\text {UML }}$ values ranging from 19 to $267 \mu \mathrm{mol}$ photons $\mathrm{m}^{-2} \mathrm{~s}^{-1}$, consistent with phytoplankton acclimating to higher growth irradiance by increasing their $(\mathrm{DD}+\mathrm{DT}) / \mathrm{chl}$ a ratio. When stations were grouped according to their dominant phytoplankton taxa, this relationship was stronger at the stations dominated by diatoms and absent at stations dominated by Phaeocystis antarctica (Fig. 4A, Table 2).

There was no relationship between the (DD + $\mathrm{DT}) / \mathrm{chl}$ a ratio and DFe concentration when all stations were considered together (Fig. 4B, Table 2). At Phaeocystis antarctica-dominated stations, the relationship was weak, slightly positive, but non- significant. The relationship at diatom-dominated stations was stronger and negative, although also non-significant due to the low sample size (Table 2). The negative slope of the relationship and relatively high $\mathrm{R}^{2}$ suggests that in diatoms, acclimation to low DFe concentrations may lead to a higher (DD + DT)/chl a ratio, although the relationship was mainly driven by Stn 160 located in the Antarctic Circumpolar Current (ACC) region, which had the lowest DFe concentrations in our survey.

The $F_{\mathrm{v}} / F_{\mathrm{m}}$ of phytoplankton in surface waters averaged $0.46 \pm 0.07$, ranging from 0.29 at the ACC station to 0.63 at Stn 140 in the SIZ (Fig. 3C). Generally, $F_{\mathrm{v}} / F_{\mathrm{m}}$ was higher close to the ice shelves, higher in PIB than in the PIP, and variable in the SIZ. $F_{\mathrm{v}} / F_{\mathrm{m}}$ was lower at the surface than at depth (Fig. 3D) as a result 
Table 2. Regression analysis of all surface stations and those dominated ( $>50 \% \mathrm{chl}$ a) by Phaeocystis antarctica or diatoms. The regressions were not significant (ns), or significant at ${ }^{*} \mathrm{p}<0.05,{ }^{* *} \mathrm{p}<0.01,{ }^{* * *} \mathrm{p}<0.001$. See Table 1 for other abbreviations

\begin{tabular}{|c|c|c|c|c|c|c|}
\hline & Factor $x$ & Factor $y$ & Linear regression & $\mathrm{n}$ & $\mathrm{R}^{2}$ & $\mathrm{p}$ \\
\hline All stations & $E_{\mathrm{UML}}\left(\mu \mathrm{mol}\right.$ quanta $\left.\mathrm{m}^{-2} \mathrm{~s}^{-1}\right)$ & $(\mathrm{DD}+\mathrm{DT}) / \mathrm{chl} a$ & $y=0.0003 x+0.083$ & 47 & 0.14 & ** \\
\hline P. antarctica & $E_{\mathrm{UML}}\left(\mu \mathrm{mol}\right.$ quanta $\left.\mathrm{m}^{-2} \mathrm{~s}^{-1}\right)$ & $(\mathrm{DD}+\mathrm{DT}) / \mathrm{chl} a$ & $y=0.0002 x+0.089$ & 37 & 0.08 & ns \\
\hline Diatom & $E_{\mathrm{UML}}\left(\mu \mathrm{mol}\right.$ quanta $\left.\mathrm{m}^{-2} \mathrm{~s}^{-1}\right)$ & $(\mathrm{DD}+\mathrm{DT}) / \mathrm{chl} a$ & $y=0.0009 x+0.056$ & 8 & 0.56 & $*$ \\
\hline All stations & $\log (\mathrm{DFe})\left(\mathrm{nmol} \mathrm{l}^{-1}\right)$ & $(\mathrm{DD}+\mathrm{DT}) / \mathrm{chl} a$ & $y=0.0089 x+0.128$ & 43 & 0.00 & ns \\
\hline P. antarctica & $\log (\mathrm{DFe})\left(\mathrm{nmol} \mathrm{l}^{-1}\right)$ & $(\mathrm{DD}+\mathrm{DT}) / \mathrm{chl} a$ & $y=0.04045 x+0.148$ & 33 & 0.11 & ns \\
\hline Diatom & $\log (\mathrm{DFe})\left(\mathrm{nmol} \mathrm{l}^{-1}\right)$ & $(\mathrm{DD}+\mathrm{DT}) / \mathrm{chl} a$ & $y=-0.2083 x-0.044$ & 7 & 0.40 & $\mathrm{~ns}$ \\
\hline All stations & $E_{\mathrm{UML}}\left(\mu \mathrm{mol}\right.$ quanta $\left.\mathrm{m}^{-2} \mathrm{~s}^{-1}\right)$ & $F_{\mathrm{v}} / F_{\mathrm{m}}$ & $y=-0.0006 x+0.531$ & 45 & 0.23 & $* * *$ \\
\hline P. antarctica & $E_{\mathrm{UML}}\left(\mu \mathrm{mol}\right.$ quanta $\left.\mathrm{m}^{-2} \mathrm{~s}^{-1}\right)$ & $F_{\mathrm{v}} / F_{\mathrm{m}}$ & $y=-0.0005 x+0.517$ & 35 & 0.26 & ** \\
\hline Diatom & $E_{\mathrm{UML}}\left(\mu \mathrm{mol}\right.$ quanta $\left.\mathrm{m}^{-2} \mathrm{~s}^{-1}\right)$ & $F_{\mathrm{v}} / F_{\mathrm{m}}$ & $y=-0.0010 x+0.571$ & 8 & 0.31 & ns \\
\hline All stations & $\log (\mathrm{DFe})\left(\mathrm{nmol} \mathrm{l}^{-1}\right)$ & $F_{\mathrm{v}} / F_{\mathrm{m}}$ & $y=0.164 x+0.611$ & 43 & 0.32 & $* * *$ \\
\hline P. antarctica & $\log (\mathrm{DFe})\left(\mathrm{nmol} \mathrm{l}^{-1}\right)$ & $F_{\mathrm{v}} / F_{\mathrm{m}}$ & $y=0.126 x+0.573$ & 33 & 0.28 & $* * *$ \\
\hline Diatom & $\log (\mathrm{DFe})\left(\mathrm{nmol} \mathrm{l}^{-1}\right)$ & $F_{\mathrm{v}} / F_{\mathrm{m}}$ & $y=0.335 x+0.773$ & 7 & 0.50 & ns \\
\hline
\end{tabular}

of high surface light, consistent with the negative relationship between $F_{\mathrm{v}} / F_{\mathrm{m}}$ and $E_{\mathrm{UML}}$ (Fig. $4 \mathrm{C}_{\text {, }}$ Table 2). This relationship was similar for stations dominated by Phaeocystis antarctica and diatoms (Table 2). Surface $F_{\mathrm{v}} / F_{\mathrm{m}}$ in the SIZ (mean: $0.47 \pm 0.07$ ) was the same as that of the polynya (mean: $0.46 \pm$ 0.07; Table 2). Moreover, the surface $F_{\mathrm{v}} / F_{\mathrm{m}}$ at $P$. antarctica-dominated stations (mean: $0.46 \pm 0.06$ ) was the same as that of diatom-dominated stations (mean: $0.44 \pm 0.09$; Table 2).

The $F_{\mathrm{v}} / F_{\mathrm{m}}$ was positively related to DFe concentrations (Fig. 4D, Table 2), indicating that low DFe conditions resulted in a decrease in $F_{\mathrm{v}} / F_{\mathrm{m}}$ both at stations dominated by Phaeocystis antarctica and by diatoms (Table 2). Although the latter relationship was not significant due to the low number of samples, it nevertheless shows a steeper slope.

\section{SIE experiments}

SIE for 20 min caused quenching of $F_{\mathrm{v}} / F_{\mathrm{m}}$ (Fig. 5 ; Table $\mathrm{S} 1$ in the supplement at www.int-res.com/ articles/suppl/m475p015_supp.pdf), resulting in a considerably high $q N$ in all experiments (Fig. $6 \mathrm{~A}, \mathrm{~B}$; Table $\mathrm{S} 1$ in the supplement). The lowest $q N$ was observed when samples were exposed to relatively low SIE $\left(<700 \mu \mathrm{mol}\right.$ photons $\left.\mathrm{m}^{-2} \mathrm{~s}^{-1}\right)$. In all experiments, the quenching relaxed during incubation under low irradiance. In 8 of the experiments, relaxation of quenching in surface samples were assessed by high temporal resolution sampling during the first 30 min (Stns 37, 94, 105, 118, 129, 135, 158, and 160; Fig. 5A,B; Table $\mathrm{S} 1$ in the supplement). In 3 of these experiments exposed to relatively low irradiance and with relatively low $q N$ (Stns 105, 118, and 129), $q E$ had relaxed after 10 min of recovery (see Fig. 5A for a typical example from Stn 105). It took longer for $q E$ to relax in the 5 other experiments (see Fig. 5B for an example from Stn 135). However, in all 8 experiments, $q E$ was fully relaxed by $t=50 \mathrm{~min}(20 \mathrm{~min}$ of exposure +30 min of recovery used to calculate the slow relaxing quenching).

Most of the quenching was fast-relaxing during the first $30 \mathrm{~min}$ of recovery under low irradiance, resulting in a high $q E$ in most experiments, especially in surface waters where $q E$ was the major component of $q N$ (Fig. 6E,F). At depth, however, $q E$ was lower, and occasionally the minor component of $q N$ (Fig. 6F).

Slowly relaxing quenching $(q I)$ was present in most experiments (Figs. 5 \& 6C,D; Table $\mathrm{S} 1$ in the supplement), although in surface samples, it was the minor component of $q N$ (Fig. 6A,C). In some subsurface samples, $q I$ was the major component of $q N$ (Fig. 6B,D). The presence of $q I$ suggests that some photoinhibition was incurred following SIE. Moreover, inhibiting D1 repair by the addition of lincomycin negatively affected recovery in most $(87 \%)$ experiments (except Stns 13, 17, and 158; Tables 1 \& 2) in both surface and deep samples, indicating that D1 repair is a basic response of these phytoplankton when exposed to excessive irradiance. In most experiments, the $F_{\mathrm{v}} / F_{\mathrm{m}}$ of lincomycin-treated samples following SIE recovered to $50-60 \%$ of the untreated samples (see Fig. 5A-C,E for examples), but in some experiments, $F_{\mathrm{v}} / F_{\mathrm{m}}$ in lincomycin-treated samples recovered to $>90 \%$ of the untreated samples (see Fig. 5D,F for examples). There was no apparent difference between Phaeocystis antarctica- or diatom-dominated experiments in their response to lincomycin (compare Stn 105 in the PIP dominated by P. antarctica and Stn 135 in the sea ice dominated by diatoms; Fig. 5A,B). Recovery of lincomycin-treated samples was generally more similar to untreated samples at 

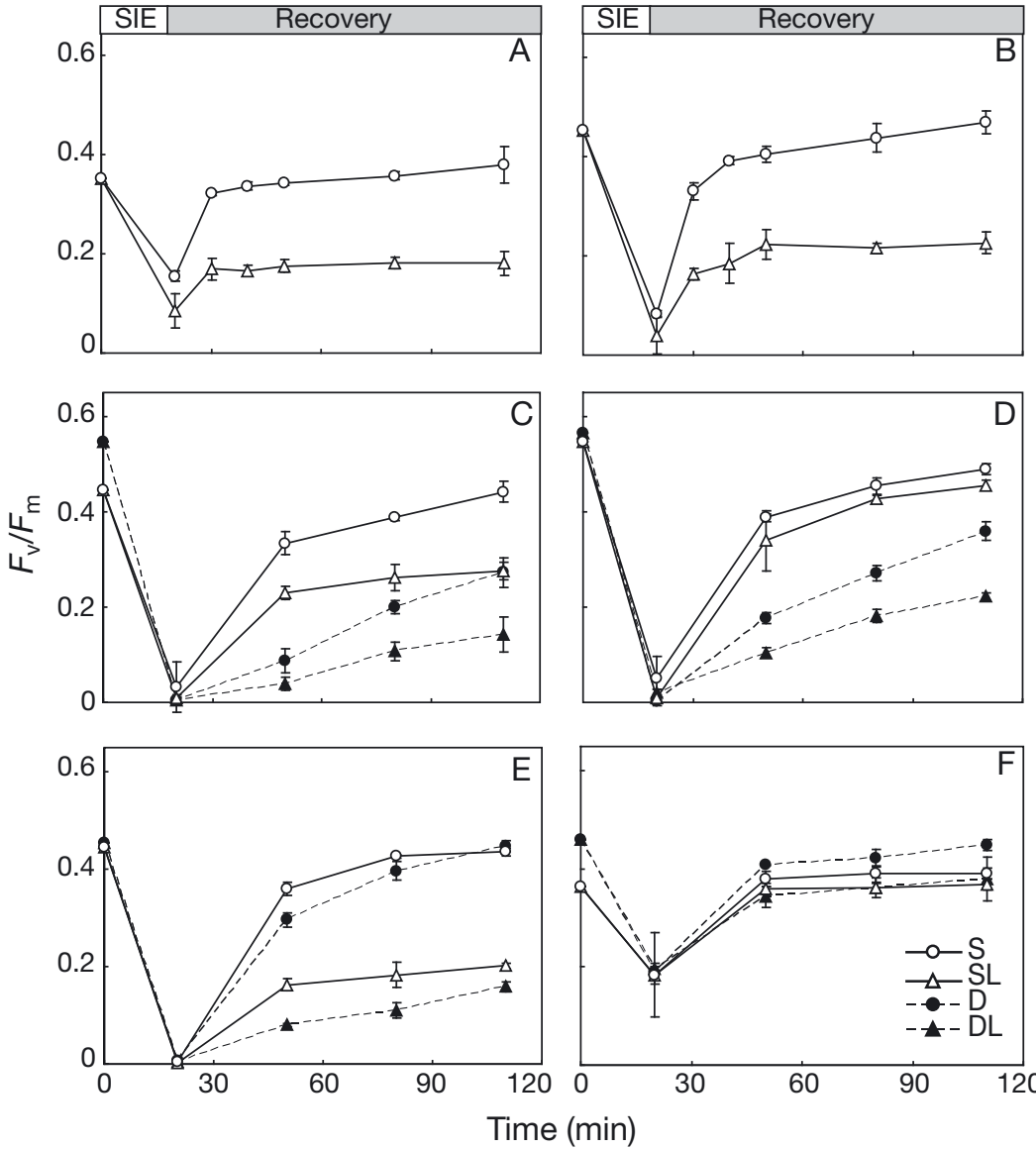

Fig. 5. Six examples of maximum efficiency of Photosystem II $\left(F_{\mathrm{v}} / F_{\mathrm{m}}\right)$ before $(t=0 \mathrm{~min})$ and after $(t=20 \mathrm{~min})$ surface irradiance exposure (SIE, units for values described below are in $\mu$ mol photons $\mathrm{m}^{-2} \mathrm{~s}^{-1}$ ) and during recovery under low irradiance for phytoplankton from the surface $(\mathrm{S}, 10 \mathrm{~m})$ and subsurface $(\mathrm{D}$, 20 to $50 \mathrm{~m}$ ) at selected stations. Mean $\pm \mathrm{SD}$ are shown for 3 replicates of untreated samples and samples with the addition of lincomycin (L). (A,B) High temporal resolution recovery of $F_{\mathrm{v}} / F_{\mathrm{m}}$ after (A) SIE of 845 in an S sample from Pine Island Polynya Stn 105 dominated by Phaeocystis antarctica and (B) SIE of 1866 in an S sample from sea ice Stn 135 dominated by diatoms. (C) SIE of 1930 in S and D $(50 \mathrm{~m})$ samples from Pine Island Bay Stn 46 dominated by P. antarctica. (D) SIE of 1991 in S and D (20 m) samples from sea ice Stn 7 dominated by $P$. antarctica. (E) SIE of 1855 in S and D $(20 \mathrm{~m})$ samples from polynya Stn 104 dominated by $P$. antarctica. (F) SIE of 335 in S and D (50 m) samples from sea ice Stn 133 dominated by diatoms

relatively low SIE (see Fig. 5F for an example from Stn 133 exposed to $335 \mu \mathrm{mol}$ photons $\mathrm{m}^{-2} \mathrm{~s}^{-1}$ ); however, in some experiments, the effect of lincomycin was small even at high SIE (see Fig. 5D for an example from Stn 7 exposed to $1991 \mu \mathrm{mol}$ photons $\mathrm{m}^{-2} \mathrm{~s}^{-1}$ ).

\section{Effects of photoacclimation state on phytoplankton response to SIE}

In 17 SIE experiments, quenching characteristics of phytoplankton were collected from both the surface
(S) and the subsurface (D) to study how light history impacts the response by phytoplankton to exposure to high surface light (Fig. 5C-F). Photoacclimation to higher light levels in the $\mathrm{S}$ sample was reflected in a higher $(\mathrm{DD}+\mathrm{DT}) / \mathrm{chl}$ a ratio in $88 \%$ of stations (except Stns 14 and 131; Table S1 in the supplement). Moreover, $F_{\mathrm{v}} / F_{\mathrm{m}}$ was lower in the $\mathrm{S}$ sample in $94 \%$ of stations (except Stn 131; Table S1 in the supplement). Out of 17 experiments, 4 experiments $(24 \%$; (Stns 7, 46, 91, and 127) exhibited a major negative effect of increased sampling depth on recovery (repeated-measures ANOVA, $\mathrm{p}<0.05$, Table $\mathrm{S} 1$ in the supplement; see Fig. 5C for a typical example at Stn 46$)$. In 10 other experiments (59\%; (Stns 11，14，17, 36, 99, 102, 104, 119, 131 , and 140), there was a small negative effect of greater sampling depth on $F_{\mathrm{v}} / F_{\mathrm{m}}$ recovery (repeated measures ANOVA, p < 0.05), and overlap between the recovery of $\mathrm{S}$ and $\mathrm{D}$ samples was observed in the controls without lincomycin (see Fig. 5E for a typical example at Stn 104). Finally, recovery of $F_{\mathrm{v}} / F_{\mathrm{m}}$ was not affected by sampling depth in 3 experiments (18\%; repeated-measures ANOVA, p > 0.05; Stns 13, 89, and 133; Table S1 in the supplement; see Fig. 5F for a typical example at Stn 133). The enhanced recovery of $\mathrm{S}$ samples was reflected in lower $q I$ and higher $q E$ (Fig. $6 \mathrm{D}, \mathrm{F}_{\text {; }}$ Table S1 in the supplement), with differences in $q N$ between $\mathrm{S}$ and $\mathrm{D}$ samples being smaller (Fig. 6B). In accordance with lower $q I$, effects of blocking D1 repair by lincomycin addition were generally less pronounced in the $\mathrm{S}$ than the $\mathrm{D}$ samples (Fig. 5C-F).

Generally, phytoplankton community composition was vertically uniform and the percent contribution of the dominant phytoplankton group in $\mathrm{S}$ and $\mathrm{D}$ samples differed by $<15 \%$, except for Stns 17 and 133, where differences were larger. Thus, at most stations, differences in phytoplankton community composition did not affect the response to SIE. In most experiments, the $\mathrm{D}$ sample was taken from below $z_{\mathrm{UML}}$, whereas in 3 experiments, both $\mathrm{S}$ and $\mathrm{D}$ 

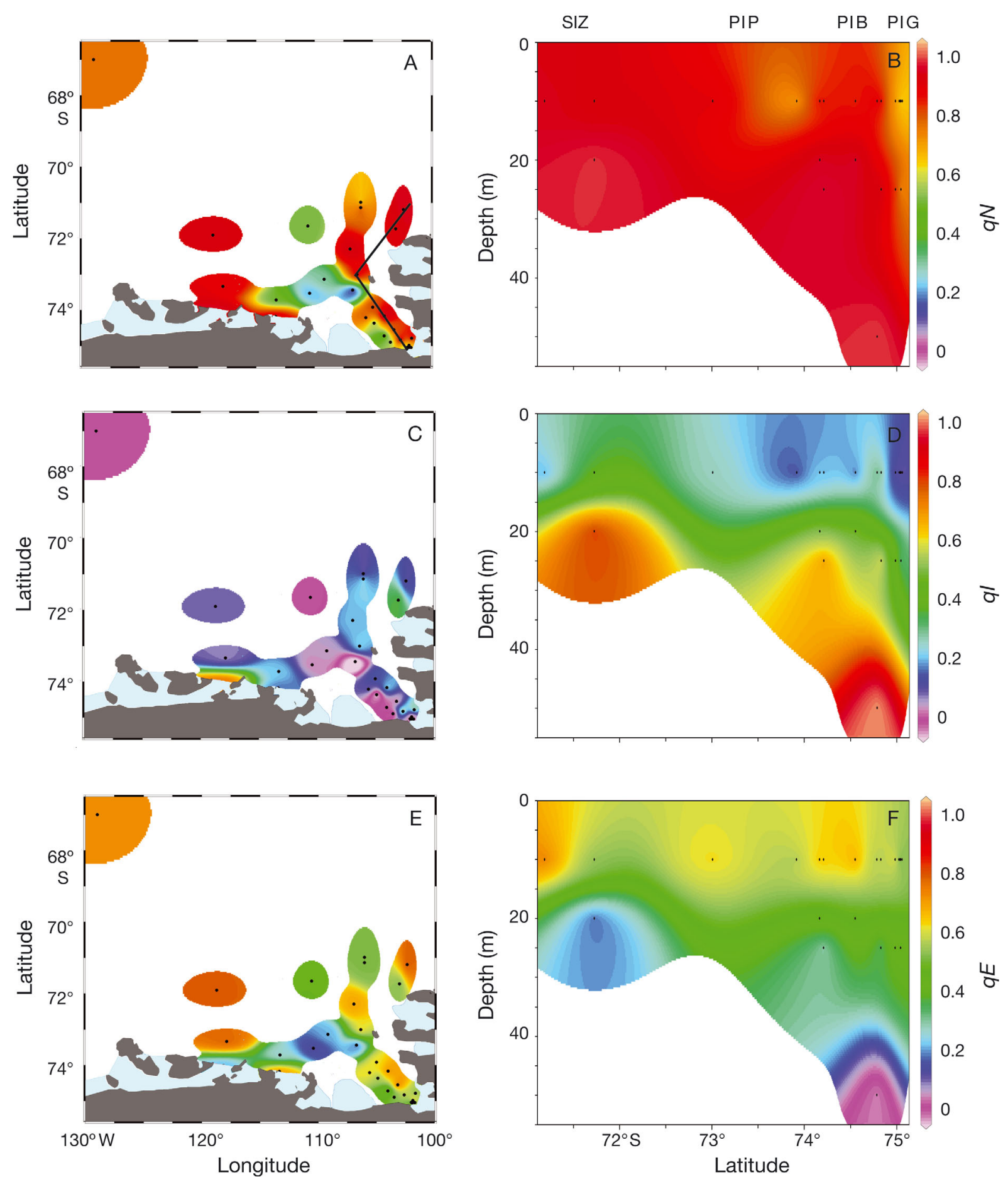

Fig. 6. $(\mathrm{A}, \mathrm{B})$ Initial non-photochemical quenching $(q N),(\mathrm{C}, \mathrm{D})$ slow-relaxing photoinhibitory quenching $(q I)$, and $(\mathrm{E}, \mathrm{F})$ fastrelaxing quenching $(q E)$ of phytoplankton after surface irradiance exposure $(\mathrm{SIE})$ in $(\mathrm{A}, \mathrm{C}, \mathrm{E})$ surface waters and on $(\mathrm{B}, \mathrm{D}, \mathrm{F})$ a transect of stations where SIE $>1500 \mu \mathrm{mol}$ photons $\mathrm{m}^{-2} \mathrm{~s}^{-1}$, from the southwestern end of Pine Island Glacier (PIG) to the northwest, transecting Pine Island Bay (PIB) and Pine Island Polynya (PIP) and the sea ice zone (SIZ), as shown by solid line in (A)

samples were collected within the UML (Stns 99, 119, and 140; (Table S1 in the supplement). These experiments showed minimal effects of sampling depth, indicating that sampling depth within the UML did not affect the magnitude of the response on quenching parameters. 


\section{Controls on phytoplankton quenching parameters}

The relationship between SIE, photoprotective pigment content, and phytoplankton quenching parameters was studied using the $\mathrm{S}$ samples of the SIE experiments $(\mathrm{n}=30)$. There was a positive relationship between $q N$ and the magnitude of SIE during
- S P. antarctica - S diatoms - S mixed red: SIE PAR > $1500 \mu \mathrm{mol}$ quanta $\mathrm{m}^{-2} \mathrm{~s}^{-1}$ black: SIE PAR $<1500 \mu$ mol quanta $\mathrm{m}^{-2} \mathrm{~s}^{-1}$
D $P$ antarctica

$\triangle$ D diatoms

$\triangle \mathrm{D}$ mixed
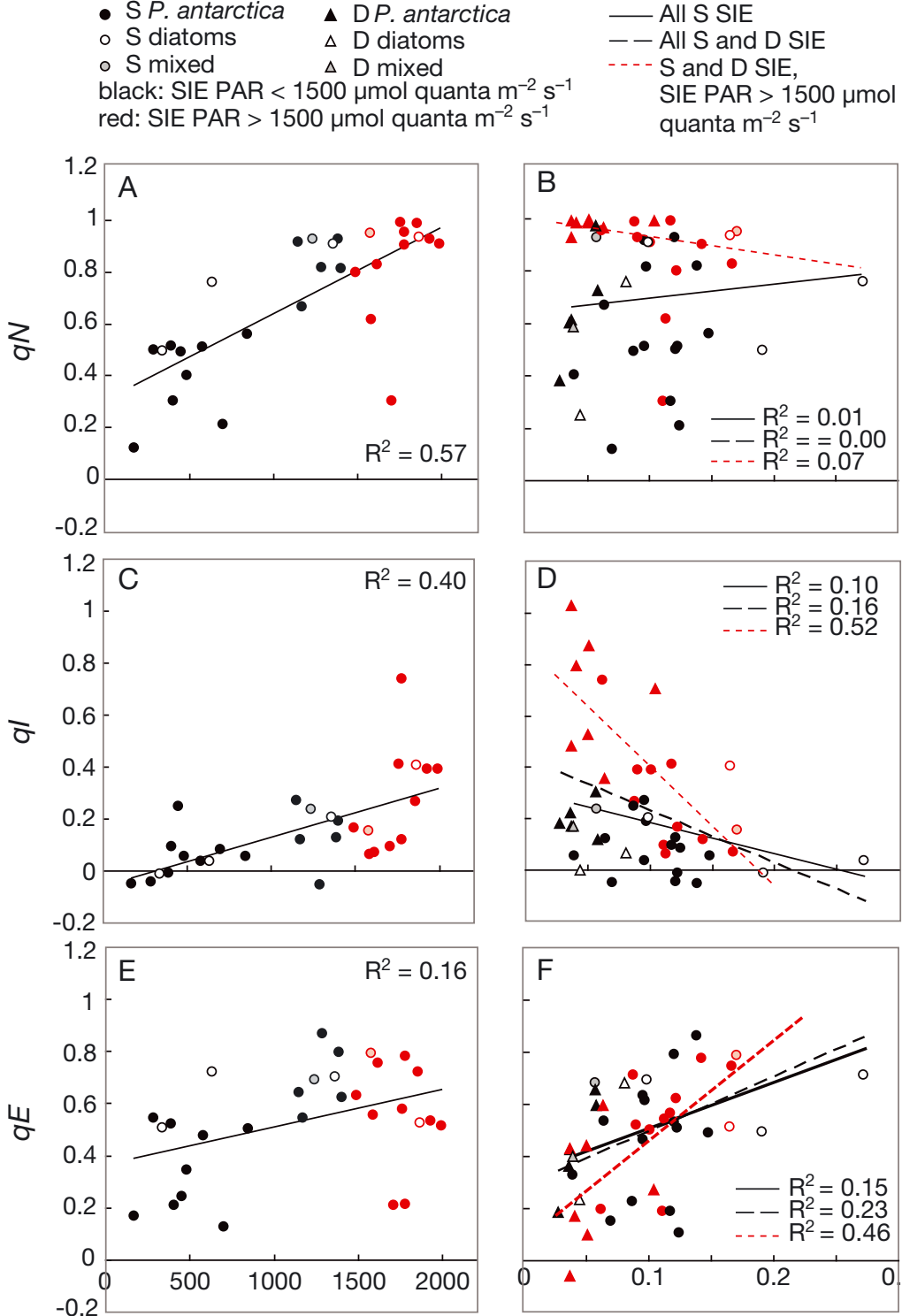

SIE ( $\mu$ mol quanta $\left.\mathrm{m}^{-2} \mathrm{~s}^{-1}\right)$
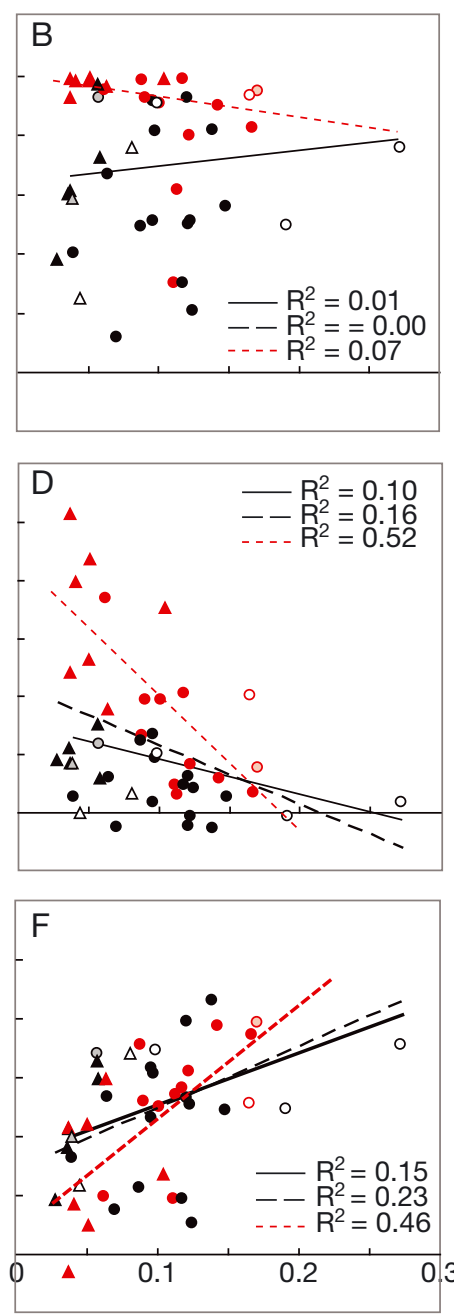

$(\mathrm{DD}+\mathrm{DT}) / \mathrm{Chl} \mathrm{a}$
Fig. 7. Relationships between $(\mathrm{A}, \mathrm{B})$ initial non-photochemical quenching $(q N),(\mathrm{C}, \mathrm{D})$ slow-relaxing photoinhibitory quenching $(q I)$, and $(\mathrm{E}, \mathrm{F})$ fast-relaxing quenching $(q E)$ to $(\mathrm{A}, \mathrm{C}, \mathrm{E})$ surface irradiance exposure $(\mathrm{SIE})$ and $(\mathrm{B}, \mathrm{D}, \mathrm{F})$ photoprotective ratio of xanthophyll cycle pigments: (diadinoxanthin $[\mathrm{DD}]+$ diatoxanthin [DT])/chl a. Samples were from the surface (S) or subsurface (D), and were dominated by Phaeocystis antarctica, diatoms, or a mixed phytoplankton community. $\mathrm{R}^{2}$ of simple linear regressions are shown; other statistics are given in Table 3 the 20 min exposure (Fig. 7A, Table 3). This relationship resulted mainly from the $q I$ component of $q N$ (Fig. 7C, Table 3) and less so from $q E$, which was less sensitive to incident irradiance during the SIE experiof excessive irradiance exposure. In contrast, $q I$ inonly when SIE exceeded 1700 umol photons $\mathrm{m}^{-2} \mathrm{~s}^{-1}$ did $q I$ exceed $q E$.

We could not discern any relationship between $E_{\mathrm{UML}}$ and the quenching parameters $q N, q I$, or $q E$ (Table 3). Thus, within the light climate to which the surface phytoplankton within the UML were acclimated, the $E_{\mathrm{UML}}$ did not affect their quenching parameters during SIE.

Relationships between the photoprotective ratio (DD $+\mathrm{DT}) / \mathrm{chl} a$ and quenching parameters were analyzed for (1) S samples only, (2) S and D samples together to include phytoplankton from below the UML that were acclimated to very low light levels and had a low (DD + DT)/chl a ratio, and (3) S and D samples exposed to high SIE (>1500 $\mu \mathrm{mol}$ photons $\mathrm{m}^{-2} \mathrm{~s}^{-1}$ ) to specifically address the effects of the $(\mathrm{DD}+\mathrm{DT}) / \mathrm{chl}$ a ratio on quenching parameters at high irradiance. There was no statistically significant relationship between the (DD + DT)/chl a ratio and $q N$ for any of the experimental treatments, including the $\mathrm{S}$ samples alone, both $\mathrm{S}$ and D samples, and when $\mathrm{S}$ and $\mathrm{D}$ samples were exposed to $>1500 \mu \mathrm{mol}$ photons $\mathrm{m}^{-2} \mathrm{~s}^{-1}$ (Fig. $7 \mathrm{~B}$, Table 3). The relationship between the $(\mathrm{DD}+\mathrm{DT}) / \mathrm{chl}$ a ratio and $q I$ was also non-significant for the $\mathrm{S}$ samples alone (Fig. 7D, Table 3). However, the relationship was stronger and slightly negative when $\mathrm{S}$ and D samples were analyzed together, although the $\mathrm{R}^{2}$ was still rather low but significant (Fig. 7D, Table 3), indicating that the photoprotective effects of the xanthophyll cycle pigment content became apparent when considered over a wider range of $(\mathrm{DD}+\mathrm{DT}) / \mathrm{chl}$ a ratios. When SIE of the S and D samples exceeded $1500 \mu \mathrm{mol}$ photons $\mathrm{m}^{-2} \mathrm{~s}^{-1}$, the slope of the regression between the (DD $+\mathrm{DT}) / \mathrm{chl}$ a ratio and $q I$ was more negative and had a higher coefficient of de- 
Table 3. Regression analysis of surface station properties and quenching parameters for surface samples, surface + subsurface samples, and surface + subsurface samples after surface irradiance exposure (SIE) of $>1500 \mu \mathrm{mol}$ quanta $\mathrm{m}^{-2} \mathrm{~s}^{-1}$ (high SIE). $\mathrm{ns:}$ not significant, $q N$ : non-photochemical quenching, $q I$ : slow-relaxing photoinhibitory quenching, $q E$ : fast-relaxing quenching. The regression were not significant (ns), or significant at ${ }^{*} \mathrm{p}<0.05,{ }^{* *} \mathrm{p}<0.01,{ }^{* * *} \mathrm{p}<0.001$. See Table 1 for other abbreviations

\begin{tabular}{|c|c|c|c|c|c|c|}
\hline & Factor $x$ & Factor $y$ & Linear regression & $\mathrm{n}$ & $\mathrm{R}^{2}$ & $\mathrm{p}$ \\
\hline Surface & SIE $\left(\mu \mathrm{mol}\right.$ quanta $\left.\mathrm{m}^{-2} \mathrm{~s}^{-1}\right)$ & $q N$ & $y=0.0003 x+0.31$ & 30 & 0.57 & $* * *$ \\
\hline Surface & SIE $\left(\mu \mathrm{mol}\right.$ quanta $\left.\mathrm{m}^{-2} \mathrm{~s}^{-1}\right)$ & $q I$ & $y=0.0002 x+0.058$ & 30 & 0.40 & $* * *$ \\
\hline Surface & SIE $\left(\mu \mathrm{mol}\right.$ quanta $\left.\mathrm{m}^{-2} \mathrm{~s}^{-1}\right)$ & $q E$ & $y=0.0001 x+0.368$ & 30 & 0.16 & * \\
\hline Surface & $E_{\mathrm{UML}}\left(\mu \mathrm{mol}\right.$ quanta $\left.\mathrm{m}^{-2} \mathrm{~s}^{-1}\right)$ & $q N$ & $y=0.0006 x+0.627$ & 30 & 0.02 & $\mathrm{~ns}$ \\
\hline Surface & $E_{\mathrm{UML}}\left(\mu \mathrm{mol}\right.$ quanta $\left.\mathrm{m}^{-2} \mathrm{~s}^{-1}\right)$ & $q I$ & $y=0.0003 x+0.125$ & 30 & 0.01 & $\mathrm{~ns}$ \\
\hline Surface & $E_{\mathrm{UML}}\left(\mu \mathrm{mol}\right.$ quanta $\left.\mathrm{m}^{-2} \mathrm{~s}^{-1}\right)$ & $q E$ & $y=0.0003 x+0.502$ & 30 & 0.01 & ns \\
\hline Surface & $(\mathrm{DD}+\mathrm{DT}) / \mathrm{chl} a$ & $q N$ & $y=0.041 x+0.723$ & 30 & 0.00 & $\mathrm{~ns}$ \\
\hline Surface + subsurface & & & $y=0.099 x+0.710$ & 46 & 0.11 & ns \\
\hline Surface + subsurface, high SIE & & & $y=-1.040 x+0.992$ & 19 & 0.07 & ns \\
\hline Surface & $(\mathrm{DD}+\mathrm{DT}) / \mathrm{chl} a$ & $q I$ & $y=-1.985 x+0.431$ & 30 & 0.15 & ** \\
\hline Surface + subsurface & & & $y=-2.008 x+0.427$ & 46 & 0.26 & ** \\
\hline Surface + subsurface, high SIE & & & $y=-4.713 x+0.878$ & 19 & 0.52 & $* * *$ \\
\hline Surface & $(\mathrm{DD}+\mathrm{DT}) / \mathrm{chl} a$ & $q E$ & $y=2.026 x+0.2923$ & 30 & 0.23 & $* * *$ \\
\hline Surface + subsurface & & & $y=2.107 x+0.284$ & 46 & 0.28 & $* * *$ \\
\hline Surface + subsurface, high SIE & & & $y=3.673 x+0.114$ & 19 & 0.46 & ** \\
\hline
\end{tabular}

termination (Fig. 7E, Table 3), indicating that a high $(\mathrm{DD}+\mathrm{DT}) / \mathrm{chl}$ a ratio protects against photoinhibitory quenching at high irradiance. Finally, there was a small but statistically significant positive relationship between the $(\mathrm{DD}+\mathrm{DT}) /$ chl $a$ ratio and $q E$ when $S$ samples were analyzed alone (Fig. 7F, Table 3). This positive relationship was stronger when both $\mathrm{S}$ and D samples were analyzed together and was stronger still when SIE for both $\mathrm{S}$ and $\mathrm{D}$ samples exceeded $1500 \mu \mathrm{mol}$ photons $\mathrm{m}^{-2} \mathrm{~s}^{-1}$ (Fig. 7F, Table 3). These results indicate that a high $(\mathrm{DD}+\mathrm{DT}) / \mathrm{chl}$ a ratio increases the capacity for $q E$ at high irradiance, which reduces the amount of photoinhibition (i.e. $q I$ is lower).

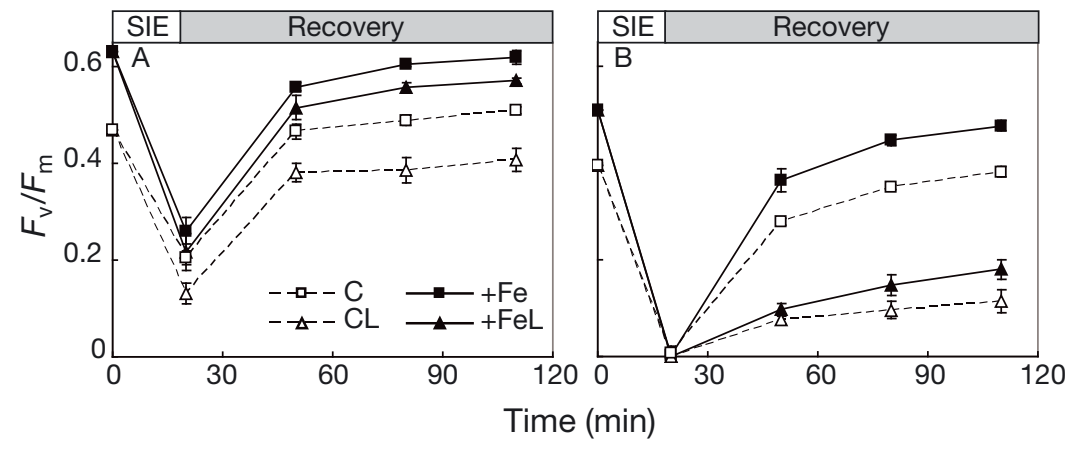

Fig. 8. Two examples of maximum efficiency of Photosystem II $\left(F_{\mathrm{v}} / F_{\mathrm{m}}\right)$ before $(t=0 \mathrm{~min})$ and after $(t=20 \mathrm{~min})$ surface irradiance exposure (SIE) and during recovery under low irradiance of phytoplankton from the unamended controls $(\mathrm{C})$ and $\mathrm{Fe}$ additions $(+\mathrm{Fe}$ ) of the bioassay experiments. Mean $\pm \mathrm{SD}$ are shown for 3 replicates of untreated samples and samples with the addition of lincomycin (L). (A) SIE of $941 \mu \mathrm{mol}$ photons $\mathrm{m}^{-2} \mathrm{~s}^{-1}$ at Stn 5 dominated by diatoms, and (B) SIE of $1270 \mu \mathrm{mol}$ photons $\mathrm{m}^{-2} \mathrm{~s}^{-1}$ at Stn 47 dominated by Phaeocystis antarctica

\section{Fe effects on phytoplankton responses to SIE}

The $+\mathrm{Fe}$ and $\mathrm{C}$ treatments of 9 bioassays were used to study Fe effects on phytoplankton photoprotection and photoinhibition after 4 to $5 \mathrm{~d}$ of incubation. The full presentation of these Fe-addition bioassays and discussion of their results with respect to Fe limitation at sample locations can be found in Mills et al. (2012). In 2 out of 9 experiments, Fe additions resulted in a $\sim 30 \%$ increase in $F_{\mathrm{v}} / F_{\mathrm{m}}$ and a $35 \%$ rise in phytoplankton biomass expressed as chl a (Stn 5 in the SIZ on the shelf break and Stn 160 in the ACC)
(Table 4), suggesting that phytoplankton in the C treatment were Fe-limited in their growth. Both experiments were dominated by diatoms (Table 4 ). Fe additions in these 2 bioassays resulted in a $35 \%$ and $18 \%$ lower $(\mathrm{DD}+\mathrm{DT}) / \mathrm{chl} a$ ratio at Stns 5 and 160 , respectively. After $\mathrm{SIE}, F_{\mathrm{v}} / F_{\mathrm{m}}$ in the $+\mathrm{Fe}$ treatments recovered to higher values than in the $\mathrm{C}$ treatments (Fig. 8A). Although there were only minor effects of Fe addition on $q N$ and $q E(<10 \%$ difference), $q I$ increased by $167 \%$ and $64 \%$ at Stns 5 and 160, respectively (Table 4 ). Thus, despite Fe additions resulting in recovery to higher $F_{\mathrm{v}} / F_{\mathrm{m}}, q I$ was still 


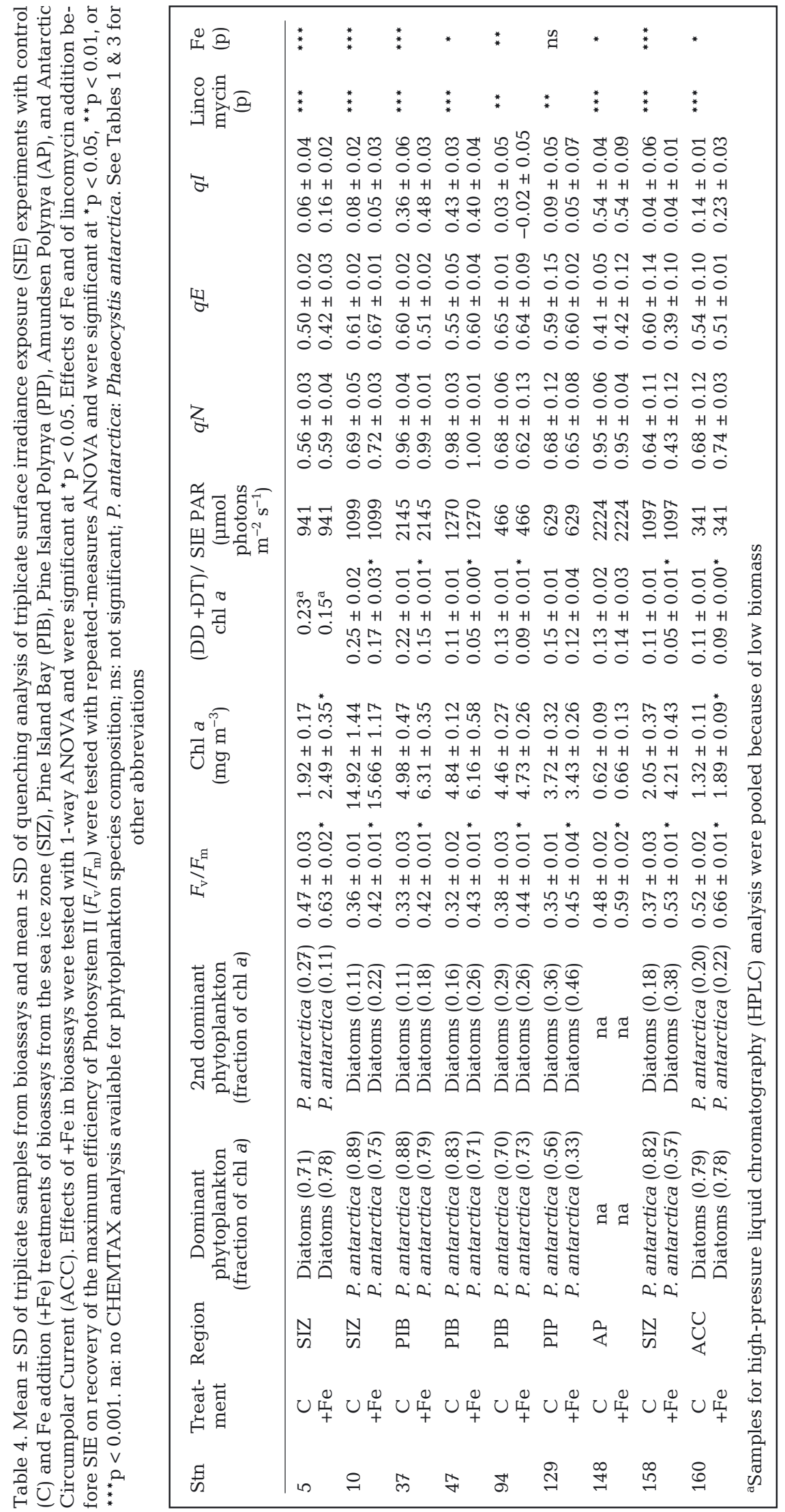

higher in the $+\mathrm{Fe}$ treatments than in the $\mathrm{C}$ treatment due to a higher $F_{\mathrm{v}} / F_{\mathrm{m}}$ at $t=0$. On the other hand, the Fe-limited, diatomdominated phytoplankton assemblages in the $\mathrm{C}$ treatment recovered to approximately their initial $F_{\mathrm{v}} / F_{\mathrm{m}}$ after SIE exposure and showed less $q I$. There was no clear effect of Fe on D1 repair in the lincomycin addition treatments at either Stn 5 or 160 , since lincomycin negatively affected recovery in both $+\mathrm{Fe}$ and $\mathrm{C}$ treatment (Fig. 8A).

In the other 7 experiments in the polynyas and SIZ, Fe addition resulted in a $27 \pm 10 \%$ increase in $F_{\mathrm{v}} / F_{\mathrm{m}}$, with no change in chl a concentrations, indicating that phytoplankton in the $\mathrm{C}$ treatment were experiencing some Fe stress but not to a degree sufficient to affect biomass over the course of the experiment. These bioassays were either dominated by Phaeocystis antarctica or contained a mixed phytoplankton population (Stn 129). Additionally, Fe additions resulted in a $41 \pm 13 \%$ lower (DD + DT)/ chl a ratio in 5 bioassays (Table 4 ), with no effect in 2 others (bioassays on Stns 129 and 148; Table 4). After SIE, there were differences in the recovery of the $+\mathrm{Fe}$ and the $\mathrm{C}$ treatment in almost all experiments (except in the bioassay of Stn 129), with the $F_{\mathrm{v}} / F_{\mathrm{m}}$ in the $+\mathrm{Fe}$ treatments increasing to values higher than in the $\mathrm{C}$ treatment (see Fig. 8B). Generally, both the $\mathrm{C}$ and Fe treatments of these mostly $P$. antarctica-dominated phytoplankton assemblages showed similar recovery characteristics with respect to their initial $F_{\mathrm{v}} / F_{\mathrm{m}}$ values (Fig. 8B), and there was little effect on quenching parameters (Table 4). There was no effect of Fe addition on $q N$, except for Stn 158 (-33\%). Similarly, Fe addition generally did not affect $q E$, except for Stns 37 $(-15 \%)$ and $159(-35 \%)$. Finally, 
Fe rarely affected $q I$, except for Stn 37 (+33\%). Moreover, blocking D1 repair by lincomycin negatively affected recovery in both the $\mathrm{C}$ and $+\mathrm{Fe}$ treatments to a similar degree (see Fig. 8B for a typical example at Stn 47), suggesting that Fe did not affect the D1 repair response in Fe-stressed, $P$. antarctica-dominated phytoplankton assemblages.

\section{DISCUSSION}

\section{Photoacclimation and photoinhibition in Phaeocystis antarctica and diatoms}

The upper water column in the Amundsen Sea was generally not very deeply mixed, with a mean $z_{\mathrm{UML}}$ of $26 \pm 24 \mathrm{~m}$ over all 46 stations. However, due to the high biomass at the time of sampling, light attenuation was high, and mixing extended below the euphotic zone at almost all stations within the PIP, PIB, and the AP (Alderkamp et al. 2012a). Moreover, moderate to high wind speeds throughout the cruise period actively mixed the UML with a high turnover rate on the order of 0.5 to $2.0 \mathrm{~h}$ (estimated according to Denman \& Gargett 1983). Thus, phytoplankton residing in the UML were subjected to a dynamic light climate that regularly exceeded $1500 \mu \mathrm{mol}$ photons $\mathrm{m}^{-2} \mathrm{~s}^{-1}$ at the surface, while $E_{\mathrm{UML}}$ was 1 to 2 orders of magnitude lower, ranging from 22 to $267 \mu \mathrm{mol}$ photons $\mathrm{m}^{-2} \mathrm{~s}^{-1}$. Consequently, phytoplankton in the UML needed to balance photoprotection with $\mathrm{CO}_{2}$ fixation under conditions ranging from light limitation to overexposure.

Both Phaeocystis antarctica and diatoms used heat dissipation by xanthophyll cycling for short-term photoprotection (Olaizola \& Yamamoto 1994, Lavaud et al. 2002a, Van de Poll et al. 2005, Van Leeuwe \& Stefels 2007), which resulted in the relatively high $q E$ observed in all SIE experiments. While traces of violaxanthin and alloxanthin were present in some of the northern SIZ surface $(10 \mathrm{~m})$ waters, DD and DT were the main xanthophyll cycle pigments that were observed throughout in the Amundsen Sea. At all stations, the (DD + DT)/chl a ratio was higher within the UML than below, confirming that both diatoms and $P$. antarctica increase their photoprotective/photosynthetic pigment ratio under high light in the UML. The (DD + DT)/chl a ratio in surface waters of diatom-dominated stations was higher than that of P. antarctica-dominated stations, although there was no difference in the $E_{\text {UML }}$ between stations dominated by these 2 groups. This observation is consistent with culture studies in which the Antarctic diatoms Fragilariopsis cylindrus and Chaetoceros brevis had a higher $(\mathrm{DD}+\mathrm{DT}) / \mathrm{chl} a$ ratio than $P$. antarctica grown over a range of light conditions (Kropuenske et al. 2009, Arrigo et al. 2010, Van de Poll et al. 2011). Moreover, the (DD + DT)/chl a ratio in surface waters increased with the $E_{\mathrm{UML}}$ at diatomdominated stations but not at those dominated by $P$. antarctica, also consistent with trends in culture studies under dynamic light with different mean light levels (Kropuenske et al. 2009). Finally, culture studies showed that the chemical inhibitors preventing the conversion of DD into heat-dissipating DT resulted in a stronger increase in photoinhibition in $F$. cylindrus than in P. antarctica (Kropuenske et al. 2009), suggesting that xanthophyll cycling is more important for photoprotection in diatoms than in P. antarctica.

Culture studies further suggested that the higher $(\mathrm{DD}+\mathrm{DT}) / \mathrm{chl}$ a ratios in diatoms enables them to grow at higher light levels and be less prone to photoinhibition than Phaeocystis antarctica (Kropuenske et al. 2009, Van de Poll et al. 2011). However, the SIE experiments in our study did not show lower $q I$ at diatom-dominated stations, and lincomycin additions negatively affected recovery of $F_{\mathrm{v}} / F_{\mathrm{m}}$ at both diatom- and $P$. antarctica-dominated stations. These results indicate that there was no difference in photoinhibition between diatoms and P. antarctica in the UML of the Amundsen Sea. Thus, differences in photoinhibition do not seem to control the relative abundances of $P$. antarctica and diatoms at stations with a dynamic light climate. However, much higher $(\mathrm{DD}+\mathrm{DT}) / \mathrm{chl}$ a ratios have been reported in diatom cultures grown at higher light levels than we encountered in our study area (Ruban et al. 2004, Van de Poll et al. 2005, 2006), suggesting that diatoms have the potential for higher $q E$ than measured here, which would be beneficial in areas with a shallow $\mathrm{UML}$ and lower biomass resulting in higher $E_{\mathrm{UML}}$.

\section{Effects of photoacclimation state on photoinhibition}

Photoacclimation to high light by phytoplankton within the UML generally resulted in higher (DD + DT)/chl a ratios, higher $q E$, and lower $q I$ than phytoplankton growing at greater depths. These results are consistent with culture studies where high (DD + DT)/chl a ratios for high light-acclimated phytoplankton provided a greater potential for $q E$ and decreased $q I$ in both diatoms and Phaeocystis antarctica (Lavaud et al. 2002a, Van de Poll et al. 2006, 2011). Moreover, high light-acclimated cultures 
showed faster de-epoxidation of xanthophyll cycle pigments after high light exposure, resulting in greater dissipation of energy, less over-excitation of PS II, and reduced photoinhibitory quenching (Van de Poll et al. 2006). Unfortunately, de-epoxidation could not be assessed in our study since sample handling and filtration took longer than the time scale of epoxidation, which is on the order of minutes (Van de Poll et al. 2006).

The $q I$ of surface phytoplankton was independent of $E_{\mathrm{UML}}$, despite a 10 -fold range in intensity (19 to $267 \mu \mathrm{mol}$ photons $\mathrm{m}^{-2} \mathrm{~s}^{-1}$ ). Thus, the light climate in the UML of the Amundsen Sea, however variable, allowed for photoacclimation of phytoplankton such that $q I$ was relatively minor at all stations. In contrast, phytoplankton in surface waters from pelagic stations in the Pacific and Atlantic sectors of the Southern Ocean and in the Drake Passage exhibited high $q I$ and low $q E$ (Alderkamp et al. 2010, 2011, Petrou et al. 2011). We do not know whether these differences were related to lower $E_{\mathrm{UML}}$ in the open-ocean studies, a different sampling season, or higher susceptibility to photoinhibition by open-ocean phytoplankton (Strzepek \& Harrison 2004, Lavaud et al. 2007). The only open-ocean station in our study (Stn 160) had a relatively high $E_{\mathrm{UML}}$ and similar quenching characteristics to the polynya stations.

Even though it was a minor fraction of $q N$, some $q I$ was observed in most SIE experiments. Elevated $q I$ and inhibition of $F_{\mathrm{v}} / F_{\mathrm{m}}$ recovery by lincomycin show that repair of D1 is a basic response by natural populations of both diatoms and Phaeocystis antarctica to excessive irradiance. A low level of repair after excessive irradiance exposure was previously observed in natural Antarctic sea-ice communities (Petrou et al. 2010) and pelagic phytoplankton communities from Palmer Stn, in response to both UVA and UVB or UVA only (Fritz et al. 2008), the latter resembling results from the SIE experiments in our study. In sta-

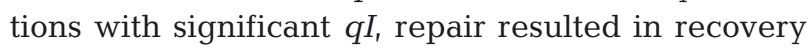
of $F_{\mathrm{v}} / F_{\mathrm{m}}$ to $>90 \%$ of its initial values within $90 \mathrm{~min}$, thus minimizing photoinhibitory effects on $\mathrm{CO}_{2}$ fixation. Rapid and continuous repair of D1 was previously reported for the green algae Dunaliella salina, whose rates of repair were proportional to growth irradiance (Kim et al. 1993). Also, when sea-ice diatoms from East Antarctic pack ice were exposed to excessive irradiance levels, the rate of D1 repair increased with increasing irradiance (Petrou et al. 2010). The rapid recovery of $F_{\mathrm{v}} / F_{\mathrm{m}}$ to initial values in experiments exhibiting $q I$ suggests that D1 damage in Antarctic phytoplankton is also repaired at low irradiance when phytoplankton are mixed down in the UML after high light exposure, thereby minimizing effects of photoinhibition on $\mathrm{CO}_{2}$ fixation.

Lincomycin addition negatively affected the recovery of $F_{\mathrm{v}} / F_{\mathrm{m}}$ in $90 \%$ of the SIE experiments, although several lincomycin-treated samples exhibited some increase in $F_{\mathrm{v}} / F_{\mathrm{m}}$ after $t=50 \mathrm{~min}$, similar to what was observed in SIE experiments in the ACC (Alderkamp et al. 2010, 2011). This apparent ability for some recovery may be due either to lincomycin not completely blocking D1 synthesis or to recovery mechanisms other than D1 repair. Immunochemistry blots of the D1 protein in natural phytoplankton samples treated with lincomycin showed a strong decrease in the D1 protein when compared to untreated controls (Bouchard et al. 2005), although some D1 remained present in lincomycin-treated samples, and thus complete inhibition of D1 synthesis could not be confirmed. Slow recovery of $F_{\mathrm{v}} / F_{\mathrm{m}}$ may also be due to slow epoxidation of DT to DD during recovery after high light exposure (Goss et al. 2006), as was reported in cultures of Antarctic diatoms Thalassiosira antarctica (Van de Poll et al. 2006) and Fragilariopsis cylindrus (Kropuenske et al. 2009). The slow recovery in lincomycin-treated samples was generally more pronounced in $\mathrm{D}$ samples than $\mathrm{S}$ samples, which corroborates results from the culture studies of Van de Poll et al. (2006), who describe slower epoxidation during recovery after high light exposure in low light-acclimated cultures than in high lightacclimated cultures. Moreover, light conditions during recovery also affect epoxidation rates (Goss et al. 2006). However, in Antarctic field samples, epoxidation was fast, and $90 \%$ of DT was converted to DD in the first 20 min of low light recovery following high light exposure (Van de Poll et al. 2011). If slow epoxidation of DT to DD affected recovery of $F_{\mathrm{v}} / F_{\mathrm{m}}$ in our study, not all measured $q I$ was the result of photodamage. Thus, our estimates of $q I$ represent an upper limit of photoinhibition in the Amundsen Sea.

In linear photosynthetic electron flow, a decrease in $F_{\mathrm{v}} / F_{\mathrm{m}}$ due to photoinhibition would decrease oxygen evolution and $\mathrm{CO}_{2}$ fixation (Long et al. 1994), although these responses do not always covary (Suggett et al. 2009). Particularly at high light, electron flow through PS II may outperform $\mathrm{CO}_{2}$ fixation (Wagner et al. 2006, Alderkamp et al. 2012b), and electrons may be shuttled to alternative electron sinks or photoprotective cycling of electrons around PS II (Lavaud et al. 2002b, Feikema et al. 2006, Alderkamp et al. 2012b). Therefore, at high light, the effect of a lower $F_{\mathrm{v}} / F_{\mathrm{m}}$ on $\mathrm{CO}_{2}$ fixation may be minimal. Since $q I$ was low in surface waters of the Amundsen Sea, effects of photoinhibition on $\mathrm{CO}_{2}$ fix- 
ation are likely to be even smaller. Accordingly, no photoinhibition of $\mathrm{CO}_{2}$ fixation was apparent in photosynthesis versus irradiance curves generated for phytoplankton that were incubated at light levels up to $600 \mu \mathrm{mol}$ photons $\mathrm{m}^{-2} \mathrm{~s}^{-1}$ (Alderkamp et al. 2012a).

\section{Effects of Fe on $q N$ and photoinhibition}

Low $\mathrm{Fe}$ concentrations in the bioassays resulted in a decrease in $F_{\mathrm{v}} / F_{\mathrm{m}}$ and an increase in the photoprotective pigment ratio (DD + DT)/chl $a$ in all diatomand most Phaeocystis antarctica-dominated experiments. An increase in the (DD + DT)/chl a ratio under Fe limitation was also observed in laboratory studies in the diatom Chaetoceros brevis (Van de Poll et al. 2005) and in P. antarctica (Van Leeuwe \& Stefels 1998, 2007, Alderkamp et al. 2012b). Moreover, bioassays in the Australian Sub-Antarctic Zone (SAZ) showed an increase in the $(\mathrm{DD}+\mathrm{DT}) / \mathrm{chl}$ a ratio under Fe limitation in a mixed phytoplankton assemblage where haptophytes were the most abundant group (Petrou et al. 2011). The increase in this ratio may be due to a decrease in cellular chl a content, an increase in cellular DD + DT concentration, or both (Greene et al. 1992).

Fe limitation may affect the ratio of components of the photosynthetic apparatus, since the amount of Fe-rich components, such as cytochrome $b_{6} f$ and Photosystem I (PS I), decrease more than others, such as those associated with PS II (Allen et al. 2008). As a result, lower cellular content of the Fe-rich cytochrome $b_{6} f$ and PS I decreases the efficiency of electron flow downstream of PS II. Since cytochrome $b_{6} f$ complexes are crucial to the build-up of the $\Delta \mathrm{pH}$ across the thylakoid membrane that drives xanthophyll de-epoxidation, and thus heat dissipation and $q E$ (Goss et al. 2006, Goss \& Jakob 2010), Fe limitation may limit photoprotection through $q E$. Moreover, it has been shown that adaptations to chronic low $\mathrm{Fe}$ concentrations in open-ocean diatoms that have lower concentrations of the Fe-rich cytochrome $b_{6} f$ and PS I reduced their potential for $q N$ and increased their susceptibility to photoinhibition (Strzepek \& Harrison 2004). However, $q N$ was mostly unaffected by $\mathrm{Fe}$ in the bioassays, whereas $q E$ was either unaffected or increased in the $-\mathrm{Fe}$ treatment. This suggests that either xanthophyll de-epoxidation was unaffected under most in situ conditions in our study, or lessened de-epoxidation was offset by a higher $(\mathrm{DD}+\mathrm{DT}) / \mathrm{chl}$ a ratio under Fe stress. The increase in $q E$ under Fe limitation is consistent with similar observations made in culture studies of the diatoms
Phaeodactylum tricornutum (Allen et al. 2008) and Fragilariopsis cylindrus (Alderkamp et al. 2012b), whereas Fe limitation did not affect $q N$ in Phaeocystis antarctica (Alderkamp et al. 2012b). Moreover, the increase in $q E$ under Fe limitation in our study corroborates increased $q E$ in an Fe-limited bioassay with a mixed phytoplankton assemblage in the open ocean of the Australian SAZ (Petrou et al. 2011), suggesting that Fe limitation increases $q E$ in natural phytoplankton assemblages.

Because of the decrease in downstream electron acceptors, acclimation to low Fe may result in a higher fraction of reduced PS II reaction centers that are more prone to photodamage (Greene et al. 1992). Despite this, acclimation to low Fe concentrations did not result in higher $q I$ in either diatom-dominated or Phaeocystis antarctica-dominated bioassays. Nor did blocking D1 repair by lincomycin affect recovery differently in $-\mathrm{Fe}$ versus $+\mathrm{Fe}$ treatments. Rather, $q I$ was diminished by $\mathrm{Fe}$ limitation in the 2 diatomdominated bioassays, corroborating a lower $q I$ in a Fe-limited bioassay conducted in the Australian SAZ (Petrou et al. 2011). Likely, the reduced chl a content of low Fe-acclimated phytoplankton reduced light absorption and over-excitation of PS II (Geider \& LaRoche 1994, Van de Poll et al. 2005, Alderkamp et al. 2012b), thereby offsetting damaging effects of more reduced PS II components. These results are consistent with culture studies showing that photoinhibition is unaffected by $\mathrm{Fe}$ limitation in both P. antarctica and Fragilariopsis cylindrus (Alderkamp et al. 2012b) and lessened in Chaetoceros brevis (Van de Poll et al. 2005).

\section{CONCLUSIONS}

Results from our field study are consistent with previous culture studies showing that Antarctic diatoms and Phaeocystis antarctica exhibit different photoacclimation strategies. Specifically, diatoms have a higher $(\mathrm{DD}+\mathrm{DT}) / \mathrm{chl} a$ ratio that can be adjusted to reflect mean light levels in a dynamic light climate, whereas the $(\mathrm{DD}+\mathrm{DT}) / \mathrm{chl}$ a ratio was lower for $P$. antarctica and did not track light levels in a dynamic light climate (Kropuenske et al. 2009, Mills et al. 2010, Van de Poll et al. 2011). However, despite the higher $(\mathrm{DD}+\mathrm{DT}) / \mathrm{chl}$ a ratios of diatoms, $q I$ was similar at diatom- and $P$. antarctica-dominated stations. Moreover, $q I$ from surface samples was relatively low, even following an SIE as high as $1500 \mu \mathrm{mol}$ quanta $\mathrm{m}^{-2} \mathrm{~s}^{-1}$, and effects of lincomycin addition were minor, never fully blocking recovery of 
$F_{\mathrm{v}} / F_{\mathrm{m}}$. Thus, photoinhibition is generally low for both diatoms and $P$. antarctica residing in the UML of the Amundsen Sea.

The low photoinhibition in UML samples resulted from photoacclimation to the available light climate, as samples acclimated to much lower light below the UML showed lower (DD + DT)/chl a ratios and higher $q I$. Despite differences in photoacclimation above and below the UML, differences in $E_{\mathrm{UML}}$ between various surface samples did not affect quenching characteristics of surface phytoplankton, indicating that the light climate in the UML of the study region enabled phytoplankton to photoacclimate to minimize photoinhibition. The increased $q I$ in samples below the UML suggests photoinhibition may be more important for phytoplankton that are mixed up to the surface from below the UML during strong mixing (e.g. during high winds). Moreover, $E_{\mathrm{UML}}$ may be much lower than observed in our study region when deep UMLs are combined with high light attenuation by phytoplankton blooms. These conditions have been observed in the Ross Sea Polynya, where the UML during Phaeocystis antarctica blooms often exceed $40 \mathrm{~m}$, with phytoplankton biomass in the order of 6 to $10 \mu \mathrm{g} \mathrm{l}^{-1} \mathrm{chl}$ a (Arrigo et al. 1999, Neale et al. 2012). In addition, early in the season, during the onset of the bloom, the shorter daylight period reduces incident irradiance. The resulting low $E_{\mathrm{UML}}$ under those conditions may prevent photoacclimation from minimizing photoinhibition.

Finally, we found no evidence that Fe limitation increases photoinhibition under realistic in situ light conditions. Although Fe limitation makes photosystems more prone to photodamage through the presence of more reduced components of the photosynthetic apparatus (Greene et al. 1992), this is likely offset by reduced excitation due to lower chl a content in combination with more photoprotection by xanthophyll pigment cycling. Thus, when phytoplankton blooms in Antarctic polynyas become Felimited (Sedwick \& DiTullio 1997), this is not likely to increase photoinhibition.

Acknowledgements. We thank the captain and crew of the RV 'Nathaniel B. Palmer', Raytheon staff, Stan Jacobs, Christopher Payne, Patrick Laan, and Charles-Edouard Thuróczy for their support. Ronald Visser is thanked for HPLC measurements. The manuscript benefited from helpful suggestions from Gemma Kulk, Molly Palmer, Willem van de Poll, Casey Smith, and Robert Strzepek. This project was funded by a National Science Foundation DynaLiFe grant to K.R.A. (ANT-0732535) as part of the International Polar Year, and by the Netherlands Organization for Scientific Research (NWO), Netherlands AntArctic Programme (NAAP grant 851.20.041).

\section{LITERATURE CITED}

Alderkamp AC, De Baar HWJ, Visser RJW, Arrigo KR (2010) Can photoinhibition control phytoplankton abundance in deeply mixed water columns of the Southern Ocean? Limnol Oceanogr 55:1248-1264

Alderkamp AC, Garcon V, De Baar HJW, Arrigo KR (2011) Short-term photoacclimation effects on photoinhibition of phytoplankton in the Drake Passage (Southern Ocean). Deep-Sea Res I 58:943-955

Alderkamp AC, Mills MM, Van Dijken GL, Laan P and others (2012a) Iron from melting glaciers fuels phytoplankton blooms in the Amundsen Sea (Southern Ocean): phytoplankton characteristics and productivity. Deep-Sea Res II 71-76:32-48

Alderkamp AC, Kulk G, Buma AGJ, Visser RJW, Van Dijken GL, Mills MM, Arrigo KR (2012b) The effect of iron limitation on the photophysiology of Phaeocystis antarctica and Fragilariopsis cylindrus under dynamic irradiance. J Phycol 48:45-59

Allen AE, Laroche J, Maheswari U, Lommer M and others (2008) Whole-cell response of the pennate diatom Phaeodactylum tricornutum to iron starvation. Proc Natl Acad Sci USA 105:10438-10443

> Aro EM, Mccaffery S, Anderson JM (1993) Photoinhibition and D1 protein-degradation in peas acclimated to different growth irradiances. Plant Physiol 103:835-843

> Arrigo KR, Robinson DH, Worthen DL, Dunbar RB, DiTullio GR, VanWoert M, Lizotte MP (1999) Phytoplankton community structure and the drawdown of nutrients and $\mathrm{CO}_{2}$ in the Southern Ocean. Science 283:365-367

Arrigo KR, Worthen DL, Robinson DH (2003) A coupled ocean-ecosystem model of the Ross Sea: 2. Iron regulation of phytoplankton taxonomic variability and primary production. J Geophys Res Oceans 108:3231, doi:10. 1029/2001JC000856

> Arrigo KR, Van Dijken GL, Long MC (2008a) Coastal Southern Ocean: a strong anthropogenic $\mathrm{CO}_{2}$ sink. Geophys Res Lett 35, L21602, doi:10.1029/2008GL035624

> Arrigo KR, Van Dijken GL, Bushinsky S (2008b) Primary production in the Southern Ocean, 1997-2006. J Geophys Res Oceans 113:C08004, doi:10.1029/2007JC 004551

Arrigo KR, Mills MM, Kropuenske LR, Van Dijken GL, Alderkamp AC, Robinson DH (2010) Photophysiology in two major Southern Ocean taxa: photosynthesis and growth of Phaeocystis antarctica and Fragilariopsis cylindrus under different irradiance levels. Integr Comp Biol 50:950-966

> Bouchard JN, Campbell DA, Roy S (2005) Effects of UV-B radiation on the D1 protein repair cycle of natural phytoplankton communities from three latitudes (Canada, Brazil, and Argentina). J Phycol 41:273-286

Boyd PW (2002) Environmental factors controlling phytoplankton processes in the Southern Ocean. J Phycol 38:844-861

$>$ De Baar HJW, Boyd PW, Coale KH, Landry MR and others (2005) Synthesis of iron fertilization experiments: from the Iron Age to the Age of Enlightenment. J Geophys Res Oceans 110:C09S16, doi:10.1029/2004JC002601

$>$ Demmig-Adams B, Adams W (2006) Photoprotection in an ecological context: the remarkable complexity of thermal energy dissipation. New Phytol 172:11-21

$>$ Denman KL, Gargett AE (1983) Time and space scales of vertical mixing and advection of phytoplankton in the upper ocean. Limnol Oceanogr 28:801-815 
Falkowski PG, LaRoche J (1991) Acclimation to spectral irradiance in algae. J Phycol 27:8-14

> Feikema WO, Marosvolgyi MA, Lavaud J, Van Gorkom HJ (2006) Cyclic electron transfer in Photosystem II in the marine diatom Phaeodactylum tricornutum. Biochim Biophys Acta 1757:829-834

Fritz JJ, Neale PJ, Davis RF, Peloquin JA (2008) Response of Antarctic phytoplankton to solar UVR exposure: inhibition and recovery of photosynthesis in coastal and pelagic assemblages. Mar Ecol Prog Ser 365:1-16

Geider RJ, La Roche J (1994) The role of iron in phytoplankton photosynthesis, and the potential for iron-limitation of primary productivity in the sea. Photosynth Res 39:275-301

Gerringa LJA, Alderkamp AC, Laan P, Thuróczy CE and others (2012) Iron from melting glaciers fuels the phytoplankton blooms in Amundsen Sea (Southern Ocean): iron biogeochemistry. Deep-Sea Res II 71-76:16-31

> Goss R, Jakob T (2010) Regulation and function of xanthophyll cycle-dependent photoprotection in algae. Photosynth Res 106:103-122

Goss R, Pinto AE, Wilhem C, Richter M (2006) The importance of a highly active and $\Delta \mathrm{pH}$-regulated diatoxanthin epoxidase for the regulation of the PS II antenna function in diadinoxanthin cycle containing algae. J Plant Physiol 163:1008-1021

> Greene RM, Geider RJ, Kolber Z, Falkowski PG (1992) Ironinduced changes in light harvesting and photochemical energy-conversion processes in eukaryotic marinealgae. Plant Physiol 100:565-575

> Hazzard C, Lesser MP, Kinzie RA (1997) Effects of ultraviolet radiation on photosynthesis in the subtropical marine diatom Chaetoceros gracilis (Bacillariophyceae). J Phycol 33:960-968

- Holm-Hansen O, Lorenzen CJ, Holms RW, Strickland JDH (1965) Fluorometric determination of chlorophyll. J Cons Int Explor Mer 30:3-15

Kim JH, Nemson JA, Melis A (1993) Photosystem II reaction center damage and repair in Dunaliella salina (green alga): analysis under physiological and irradiance-stress conditions. Plant Physiol 103:181-189

> Krause GH, Weis E (1991) Chlorophyll fluorescence and photosynthesis: the basics. Annu Rev Plant Physiol Plant Mol Biol 42:313-349

Kropuenske LR, Mills MM, Van Dijken GL, Bailey S, Robinson DH, Welschmeyer NA, Arrigo KR (2009) Photophysiology in two major Southern Ocean phytoplankton taxa: photoprotection in Phaeocystis antarctica and Fragilariopsis cylindrus. Limnol Oceanogr 54:1176-1196

Lavaud J, Rousseau B, Van Gorkum HJ, Etienne A (2002a) Influence of the diadinoxanthin pool size on photoprotection in the marine planktonic diatom Phaeodactylum tricornutum. Plant Physiol 129:1398-1406

> Lavaud J, Van Gorkom HJ, Etienne AL (2002b) Photosystem II electron transfer cycle and chlororespiration in planktonic diatoms. Photosynth Res 74:51-59

> Lavaud J, Strzepek RF, Kroth PG (2007) Photoprotection capacity differs among diatoms: possible consequences on the spatial distribution of diatoms related to fluctuations in the underwater light climate. Limnol Oceanogr 52:1188-1194

> Long MC, Dunbar RB, Tortell PD, Smith WO, Mucciarone DA, DiTullio GR (2011) Vertical structure, seasonal drawdown, and net community production in the Ross Sea, Antarctica. J Geophys Res Oceans 116:C10029, doi:10.1029/2009JC005954
Long SP, Humphries S, Falkowski PG (1994) Photoinhibition of photosynthesis in nature. Annu Rev Plant Physiol Plant Mol Biol 45:633-662

> Lovenduski NS, Gruber N (2005) Impact of the Southern Annular Mode on Southern Ocean circulation and biology. Geophys Res Lett 32:L11603, doi:10.1029/2005 GL022727

MacIntyre HL, Kana TM, Geider RJ (2000) The effect of water motion on short-term rates of photosynthesis by marine phytoplankton. Trends Plant Sci 5:12-17

Mackey MD, Mackey DJ, Higgins HW, Wright SW (1996) CHEMTAX - a program for estimating class abundances from chemical markers: application to HPLC measurements of phytoplankton. Mar Ecol Prog Ser 144: 265-283

Maxwell K, Johnson GN (2000) Chlorophyll fluorescencea practical guide. J Exp Bot 51:659-668

Mills MM, Kropuenske LR, Van Dijken GL, Alderkamp AC and others (2010) Photophysiology in two Southern Ocean phytoplankton taxa: photosynthesis of Phaeocystis antarctica (Prymnesiophyceae) and Fragilariopsis cylindrus (Bacillariophyceae) under simulated mixedlayer irradiance. J Phycol 46:1114-1127

Mills MM, Alderkamp AC, Thuróczy CE, Van Dijken GL, De Baar HJW, Arrigo KR (2012) Phytoplankton biomass and pigment responses to Fe amendments in the Pine Island and Amundsen polynyas. Deep-Sea Res II 71-76:61-76

> Neale PJ, Sobrino C, Gargett AE (2012) Vertical mixing and the effects of solar radiation on photosystem II electron transport by phytoplankton in the Ross Sea Polynya. Deep-Sea Res I 63:118-132

> Olaizola M, Yamamoto HY (1994) Short-term response of the diadinoxanthin cycle and fluorescence yield to high irradiance in Chaetoceros muelleri (Bacillariophyceae). J Phycol 30:606-612

> Petrou K, Hill R, Brown CM, Campbell DA, Doblin MA, Ralph PJ (2010) Rapid photoprotection in sea-ice diatoms from the East Antarctic pack ice. Limnol Oceanogr 55: 1400-1407

> Petrou K, Hassler CS, Doblin MA, Shelly K and others (2011) Iron-limitation and high light stress on phytoplankton populations from the Australian Sub-Antarctic Zone (SAZ). Deep-Sea Res II 58:2200-2211

Ruban A, Lavaud J, Rousseau B, Guglielmi G, Horton P, Etienne AL (2004) The super excess dissipation in diatom algae: comparative analysis with higher plants. Photosynth Res 82:165-175

- Schoemann V, Becquevort S, Stefels J, Rousseau V, Lancelot C (2005) Phaeocystis blooms in the global ocean and their controlling mechanisms: a review. J Sea Res 53: 43-66

> Sedwick PN, DiTullio GR (1997) Regulation of algal blooms in Antarctic shelf waters by the release of iron from melting sea ice. Geophys Res Lett 24:2515-2518

- Strzepek RF, Harrison PJ (2004) Photosynthetic architecture differs in coastal and oceanic diatoms. Nature 431: 689-692

> Suggett DJ, Moore CM, Hickman AE, Geider RJ (2009) Interpretation of fast repetition rate (FRR) fluorescence: signatures of phytoplankton community structure versus physiological state. Mar Ecol Prog Ser 376:1-19

Sunda WG, Huntsman SA (1997) Interrelated influence of iron, light and cell size on marine phytoplankton growth. Nature 390:389-392

Van de Poll WH, Van Leeuwe MA, Roggeveld J, Buma AGJ 
(2005) Nutrient limitation and high irradiance acclimation reduce PAR and UV-induced viability loss in the Antarctic diatom Chaetoceros brevis (Bacillariophyceae). J Phycol 41:840-850

Van de Poll WH, Alderkamp AC, Janknegt PJ, Roggeveld J, Buma AGJ (2006) Photoacclimation modulates excessive photosynthetically active and ultraviolet radiation effects in a temperate and an Antarctic marine diatom. Limnol Oceanogr 51:1239-1248

Van de Poll WH, Janknegt PJ, Visser RJW, Buma AGJ (2009) Excessive irradiance and antioxidant responses of an Antarctic marine diatom exposed to iron limitation and to dynamic irradiance. J Photochem Photobiol B Biol 94: 32-37

> Van de Poll WH, Lagunas M, De Vries T, Visser RJW, Buma AGJ (2011) Non-photochemical quenching of chlorophyll fluorescence and xanthophyll cycle responses after excess PAR and UVR in Chaetoceros brevis, Phaeocystis antarctica and coastal Antarctic phytoplankton. Mar Ecol Prog Ser 426:119-131

Van Kooten O, Snell JFH (1990) The use of chlorophyll fluorescence nomenclature in plant stress physiology. Photosynth Res 25:147-150

Van Leeuwe MA, Stefels J (1998) Effects of iron and light stress on the biochemical composition of Antarctic Phaeocystis sp. (Prymnesiophyceae). II. Pigment composition. J Phycol 34:496-503

Editorial responsibility: Graham Savidge,

Portaferry, UK
Van Leeuwe MA, Stefels J (2007) Photosynthetic responses in Phaeocystis antarctica towards varying light and iron conditions. Biogeochemistry 83:61-70

> Vassiliev IR, Kolber Z, Wyman KD, Mauzerall D, Shukla VK, Falkowski PG (1995) Effects of iron limitation on photosystem-II composition and light utilization in Dunaliella tertiolecta. Plant Physiol 109:963-972

Vernet M, Martinson D, Iannuzzi R, Stammerjohn S and others (2008) Primary production within the sea-ice zone west of the Antarctic Peninsula: I-sea ice, summer mixed layer, and irradiance. Deep-Sea Res II 55: 2068-2085

Wagner H, Jakob T, Wilhelm C (2006) Balancing the energy flow from captured light to biomass under fluctuating light conditions. New Phytol 169:95-108

Wright SW, Thomas DP, Marchant HJ, Higgins HW, Mackey MD, Mackey DJ (1996) Analysis of phytoplankton of the Australian sector of the Southern Ocean: comparisons of microscopy and size frequency data with interpretations of pigment HPLC data using the 'CHEMTAX' matrix factorisation program. Mar Ecol Prog Ser 144:285-298

- Wright SW, Van den Enden RL, Pearce I, Davidson AT, Scott FJ, Westwood KJ (2010) Phytoplankton community structure and stock in the Southern Ocean $\left(30-80^{\circ} \mathrm{E}\right)$ determined by CHEMTAX analysis of HPLC pigment signatures. Deep-Sea Res II 57:758-778

Submitted: June 15, 2012; Accepted: October 8, 2012 Proofs received from author(s): January 31, 2013 